\title{
ALCOHOL REGULATION AND VIOLENCE ON COLLEGE CAMPUSES
}

\author{
Michael Grossman \\ Sara Markowitz \\ Working Paper 7129 \\ http://www.nber.org/papers/w7129 \\ NATIONAL BUREAU OF ECONOMIC RESEARCH \\ 1050 Massachusetts Avenue \\ Cambridge, MA 02138 \\ May 1999
}

The views expressed herein are those of the authors and do not necessarily reflect the views of the National Bureau of Economic Research.

0 1999 by Michael Grossman and Sara Markowitz. All rights reserved. Short sections of text, not to exceed two paragraphs, may be quoted without explicit permission provided that full credit, including ${ }^{\circ}$ notice, is given to the source. 
Alcohol Regulation and Violence on College Campuses

Michael Grossman and Sara Markowitz

NBER Working Paper No. 7129

May 1999

JEL No. I10

ABSTRACT

This study focuses on the effects of variations in alcoholic beverage prices among states of the United States on violence on college campuses. The principal hypothesis tested is that the incidence of violence is negatively related to the price of alcohol. This hypothesis is derived from two well established relationships: the positive relationship between alcohol and violence and the negative relationship between the use of alcohol and its price. The data employed in the study are the 1989, 1990, and 1991 Core Alcohol and Drug Surveys of College Students. They contain almost 120,000 college students from approximately 200 colleges and universities throughout the United States and have measures of alcohol use and the adverse consequences of its use. These adverse consequences include the following indicators of violence: getting in trouble with the police, residence hall, or other college authorities; damaging property or pulling a fire alarm; getting into an argument or a fight; and taking advantage of another person sexually or having been taken advantage of sexually. The principal finding is that the incidence of each of these four acts of violence is inversely related to the price of beer in the state in which the student attends college.

Michael Grossman

City University of New York Graduate School NBER

50 East 42nd Street, 17th floor

New York, New York 10017-5405

mgrossman@gc.cuny.edu
Sara Markowitz

New Jersey Institute of Technology NBER

50 East 42nd Street, 17th floor New York, New York 10017-5405 markowit@megahertz.njit.edu 


\section{Introduction}

This paper is a contribution to the literature on the effects of alcohol regulation on the adverse consequences of alcohol abuse. Previous research has considered such outcomes as cirrhosis mortality (Cook and Tauchen 1982; Saffer 1991); motor vehicle accident mortality (Saffer and Grossman 1987; Chaloupka, Saffer, and Grossman 1993; Ruhm 1996); failure to complete college (Cook and Moore 1993a); and drunk driving (Kenkel 1993; Sloan, Reilly, and Schenzler 1995). These studies have found that increases in the price of alcohol, which various levels of government regulate via taxation, lead to reductions in the adverse outcomes just mentioned.

Our study focuses on the effects of variations in alcoholic beverage prices among states of the United States on violence on college campuses. The principal hypothesis tested is that the incidence of violence is negatively related to the price of alcohol. This hypothesis is derived from two well established relationships: the positive relationship between alcohol and violence and the negative relationship between the use of alcohol and its price. The data employed in the study are the 1989, 1990, and 1991 Core Alcohol and Drug Surveys of College Students. Combined these surveys contain almost 120,000 college students from approximately 200 colleges and universities throughout the United States. They contain measures of the use of alcohol and the adverse consequences of its use. These adverse consequences include the following indicators of violence: getting in trouble with the police, residence hall, or other college authorities; damaging property or pulling a fire alarm; getting into an argument or a fight; and taking advantage of another person sexually or having been taken advantage of sexually. Our principal finding is that the incidence of each of these four acts of violence is inversely related to the price of beer in the state in which the student attends college. 


\section{Background}

By July 1988, each state of the United States had enacted legislation barring persons under the age of 21, many of whom are college students, from purchasing and consuming alcohol. Despite this legislation, consumption of alcohol by underage youths hardly has been eliminated. Approximately 73 percent of all high school seniors consumed alcohol in the past year in 1996 and 30 percent engaged in binge drinking (consumption of five or more drinks in a row) in the past two weeks in that year (Johnston, O’Malley, and Bachman 1997). In 1993, 81 percent of underage college students consumed alcohol in the past year and 45 percent engaged in binge drinking in the past two weeks (Chaloupka and Wechsler 1996). The almost annual occurrence of the death of at least one fraternity pledge due to alcohol poisoning is a stark reminder of the extent and serious consequences of alcohol abuse on college campuses.

The role played by alcohol in violence is well known. The National Institute on Alcohol Abuse and Alcoholism deemed this relationship of sufficient importance to issue a conference volume dealing with it in 1993 (Martin 1993). Alcohol is present in a large proportion of violent events, including between one-half and two-thirds of all homicides and serious assaults involving adults and adolescents and many reported instances of family violence (Wolfgang 1958; Viscusi 1986; Pernanen 1981, 1991, 1993; Cordilia 1985; Cook and Moore 1993b; Fagan 1993a, 1993b). The Bureau of Justice Statistics $(1988,1998)$ highlights this relationship in more detail. About half of the inmates in surveys conducted by the BJS drank an average of one ounce or more of alcohol daily, while only one-tenth of the adult population consumed this quantity. Over twenty percent of inmates were consuming the equivalent of nine ounces of 80 proof liquor or eight cans of beer daily during the year before the crime. Probationers and inmates reported consuming the equivalent of between nine and fifteen beers during a period of up to eight hours prior to the 
crime.

Alcohol is more prevalent in violent crimes than in other crimes. In 1997, about 45 percent of state prisoners convicted of assault or murder had used alcohol just before committing the crime (BJS 1999). On the other hand, about 37 percent of burglars and 27 percent of drug offenders (those convicted of possession or distribution) used alcohol just prior to the crime for which they were convicted.

There is no general agreement in the literature concerning the nature of the causality implied by the positive association between alcohol and violence. Theories range from simple pharmacological effects to the complex interaction of endocrinological, neurobiologic, environmental, social and cultural determinants (Goldstein 1985; Reiss and Roth 1993). For example, there may exist a psychopharmacological relationship in which alcohol can alter behavior by increasing excitability and/or boosting courage (Pernanen 1981; Fagan 1993a). Under this theory, people may be more likely to commit a violent act when under the influence of alcohol than they would otherwise. A second theory proposes that alcohol affects the brain in such a way that people misinterpret social cues with the result of violent reactions (Collins and Schlenger 1988). A third theory asserts that people's reactions to alcohol follow what society has taught them to believe it does. For example, in the United States, people are taught that alcohol and drug use may cause people to lose their inhibitions and/or release violent tendencies, and thus users cannot be blamed fully for their actions. In other words, drunkenness may give people an excuse for aberrant behavior, despite whether or not actual pharmacological effects exist (Gelles and Cornell 1990).

The theories just summarized indicate that the statistical association between drinking and violence does not necessarily reflect causality from alcohol consumption to violence. The 
relationship may be due to reverse causality or to differences in one or more "third variables" that affect both violence and alcohol use in the same direction. Reverse causality results when the decision to engage in violent acts stimulates drinking to provide an excuse or to provide courage. The third variable explanation points to such factors as a risk-seeking personality or a social environment that encourages deviant behavior (Fagan 1993b).

Prior to the early 1990s economists had contributed little to the phenomenon of alcoholrelated violence. Cook and Moore (1993b) point out that this can be explained on empirical and theoretical grounds. Empirically, economists often are reluctant to focus on relationships in which the direction and degree of causality appear to be difficult to establish. Theoretically, economists typically assume rational behavior, but this assumption may not hold in the case of alcohol-related violence.

Cook and Moore (1993b) proceed to argue that the rational economic model can be applied to alcohol-related violence and that this approach has in fact been adopted by researchers in other disciplines (for example, Pernanen 1991). Thus, consider a man who deliberately abuses his wife or child to control their behavior or to increase his share in family resources along the lines of an economic model of domestic violence proposed by Long, Witte, and Karr (1983) and by Tauchen, Witte, and Long (1991). The actual cost of this action is lower if the abuser expects that his victims will attribute his actions to alcohol rather than directly hold him responsible. In the former case, the victims may be more likely to forgive the abuser. Alcohol can also lower the perceived costs of violence, many of which occur in the future. Heavy alcohol consumption is likely to increase the discount factor that potential offenders apply to future costs. Thus, it may make the commission of a violent act more likely. Cook and Moore (1993b) also refer to a model proposed by several economists in which consumers have stable but inconsistent short-run 
and long-run preferences (for example, Schelling 1978; Thaler and Shefrin 1981). Excessive alcohol consumption raises the costs of self-management and makes it more likely that decisions will be dominated by the preferences of the myopic doer rather than by the far-sighted planner.

Although it is not mentioned by Cook and Moore, the rational addiction model developed by Becker and Murphy (1988) and expanded by Becker, Grossman, and Murphy (1991) can also be used to justify an economic approach to alcohol-related violence. In the Becker-Murphy model rational utility-maximizing consumers may become addicted to the consumption of harmful goods such as cigarettes, illegal drugs, and alcohol consumption. In their framework consumers are rational or farsighted in the sense that they anticipate the expected future consequences of their current actions. They choose to consume these goods because the marginal benefit of current consumption exceeds the expected future marginal costs. These goods are addictive if an increase in past consumption raises current consumption because it raises the marginal benefit of current consumption by more than it raises the expected future marginal costs. Becker and Murphy also show that a myopic model of addiction--one in which consumers ignore the future consequences of their current actions--is a special case of their general approach to addiction. The key point to note is that alcohol-related violence can be viewed as an anticipated or unanticipated consequence of the addictive consumption of excessive amounts of alcohol.

The importance of the economic models of violence summarized by Cook and Moore and the Becker-Murphy addiction model is that they all contain demand functions for alcohol in which the quantity of alcohol demanded by an individual is negatively related to its price and to other exogenous determinants such as income and tastes or preferences. Chaloupka and Saffer (1992), Cook and Moore (1993b), and Markowitz and Grossman $(1998,1999)$ have used this 
approach to estimate reduced form violence equations that result when alcohol consumption, an endogenous variable in a structural violence equation, is replaced by its determinants. Both Chaloupka and Saffer (1992) and Cook and Moore (1993b) investigate the effects of variations in beer tax rates among states of the United States on various crime rates from the Federal Bureau of Investigation's Uniform Crime Reports (UCR) in a time series of state cross sections for the period 1975 through 1990 (Chaloupka and Saffer) and for the period 1979 through 1987 (Cook and Moore). Both include the violent crimes of murder, rape, assault, and robbery; while Chaloupka and Saffer also consider burglary, larceny, and motor vehicle theft. Cook and Moore adopt a fixed-effects specification in which the only regressors other than the beer tax are dichotomous variables for each state except one and each year except one. Saffer and Chaloupka adopt a more fully specified model of the determinants of crime. Both studies find that increases in beer tax rates lead to statistically significant reductions in most of the crime rates. For example, Chaloupka and Saffer predict that a doubling of the federal beer tax would reduce murders by 3 percent, rapes by 3 percent, robberies by 4.7 percent, and burglaries and thefts by 1.3 percent each. Cook and Moore estimate that a 10 percent increase in the state beer tax rate would reduce murder and assaults by 0.3 percent each, rapes by 1.3 percent, and robbery by 0.9 percent.

Markowitz and Grossman (1998) use the 1976 National Family Violence Survey to examine the effects of variations in state beer tax rates on the incidence and amount of severe and overall violence directed at children by parents. Acts of severe violence include kicking, biting or hitting with fist; hitting or trying to hit with something; beating up the child; threatening with a gun or knife; or using a knife or gun. Overall violence includes these behaviors as well as the minor acts of violence of throwing something at the child and pushing, grabbing or shoving 
the child. We find that a 10 percent increase in the beer tax will reduce the probability of severe violence by 2.3 percent, the probability of overall violence by 1.2 percent, and the number of violent acts by parents who commit these acts by 1.6 percent. By pooling data from the 1985 and 1976 National Family Violence Surveys with a set of state dummies, Markowitz and Grossman (1999) show that the negative tax effects are not due to unobserved state factors.

\section{Analytical Framework}

We adopt the framework employed in our previous studies (Markowitz and Grossman $1998,1999)$ to generate reduced form equations for acts of violence committed by students on college campuses. Our framework is sufficiently broad to accommodate cases in which the violence caused by alcohol consumption or excessive consumption yields negative utility and cases in which violence or the power, control, or other outcome that it produces is a positive source of utility. In the former case the negative consequences can be anticipated or unanticipated. If they are anticipated, the positive marginal utility of alcohol consumption must outweigh the negative marginal utility of violence. If the consequences are unanticipated, alcohol consumption can be positive even if this condition is not satisfied. Whether the consequences are anticipated or unanticipated, by the law of the downward-sloping demand function, an increase in the price of alcohol causes a reduction in consumption and a reduction in violence. $^{1}$

The above ideas are formalized in a three-equation econometric model. The first equation is a structural equation for violence:

$$
\mathrm{v}=\mathrm{v}(\mathrm{a}, \mathrm{x}) .
$$

Here $\mathrm{v}$ is a measure of violence, $\mathrm{a}$ is alcohol consumption and $\mathrm{x}$ is a vector of demographic, 
socioeconomic, and personal characteristics. Some of the members of the $\mathrm{x}$ vector, such as a risk-seeking personality or a social environment that encourages deviant behavior, are not observed. The second equation is a demand function for alcohol:

$$
\mathrm{a}=\mathrm{a}(\mathrm{p}, \mathrm{y})
$$

where $\mathrm{p}$ is the price of alcohol and $\mathrm{y}$ is a vector of other determinants of consumption.

Substituting equation (2) into equation (1), one obtains a reduced form violence equation:

$$
\mathrm{v}=\mathrm{v}(\mathrm{p}, \mathrm{x}, \mathrm{y})
$$

We estimate the demand function and the reduced form violence equation by ordinary least squares. Our focus is on the third equation and on the coefficient of the price of alcohol in that equation. In addition we estimate equation (1), the structural violence equation, in which alternative acts of violence depend on alcohol consumption--an endogenous right-hand side variable. We estimate this equation by two-stage least squares for two reasons. First, the vectors $\mathrm{x}$ and y may share common unobserved variables. Second, as noted in Section II, the relationship between alcohol consumption and violence may be due in part to reverse causality from violence to consumption. In either case, the disturbance term in the equation is correlated with observed alcohol consumption. Identification is achieved in the context of the two-stage least squares approach by imposing the restriction that the price of alcohol should have no impact on violence with alcohol consumption held constant.

\section{Data and Empirical Implementation}

Data on criminal behavior on college campuses, alcohol consumption, and individual student characteristics come from the 1989, 1990, and 1991 Core Alcohol and Drug Surveys of College Students (hereafter termed the Core Surveys), conducted by the University of Southern 
Illinois's Core Institute (a Center for Alcohol and Drug Studies) and described in detail by Presley, Meilman, and Lyerla $(1993,1995)$ and by Presley et al. (1996). Each of the three surveys contains approximately 50,000 college students. Taken together, 238 different colleges from 46 states are represented in the three surveys. These are colleges receiving two-year grants from the Fund for the Improvement of Postsecondary Education (FIPSE) of the U.S. Department of Education to establish substance abuse programs. Student demographics at these colleges are similar to those of American colleges and universities generally. The Core Institute requested that FIPSE colleges administer the Core Survey on their campuses prior to the establishment of the substance abuse program using representative sampling techniques. The survey focuses on the use of alcohol and illegal drugs and on the consequences of this use.

For reasons of confidentiality, the only information on the college available to us is the state in which it is located. Moreover, the information on student and family background characteristics (described below) is limited. Therefore, to control for unmeasured factors and to avoid distorting trends, we restrict the sample to colleges in one of the 29 states that was in the 1989 survey. ${ }^{2}$ These states accounted for 80 percent of the population of the United States in 1990. Our final sample contains 122,416 students from 191 colleges and universities.

Definitions, means, and standard deviations of all variables employed in the regressions in Section IV are given in Table 1. Dichotomous indicators of the incidence of four alternative types of violent behavior due to drinking or illegal drug use in the past year are employed as outcomes in linear probability regression models. ${ }^{3}$ They are: getting in trouble with the police, residence hall, or other college authorities (termed trouble); damaging property, pulling a fire alarm, etc. (termed damage); getting into an argument or a fight (termed fight); and taking advantage of another person sexually or having been taken advantage of sexually (termed sexual 
advantage). Their incidence rates are 12.4 percent for trouble, 7.6 percent for damage, 31.3 percent for fight, and 14.4 percent for sexual advantage. ${ }^{4}$ Some behaviors in the first category (trouble) may be more appropriately categorized as mischief rather than as crime, and the first two outcomes (trouble and damage) do not necessarily involve violent behavior. We use the term violence to describe all four behaviors because the simple correlations among them, which range from 0.23 to 0.36 , are fairly high. Moreover, persons who break laws governing nonviolent behavior may be more likely to break laws governing violent behavior.

Due to the way in which the violence questions are worded, respondents are supposed to be reporting behavior caused by the use of alcohol or illegal drugs. This increases the value of these behaviors in assessing the effects of changes in the cost of alcohol on violence but decreases their value in assessing the overall contribution of alcohol abuse to violence. Of course, violence can be caused by more than one factor, and alcohol is present in a large proportion of violent and non-violent criminal events as indicated in Section I. Thus, on balance the benefits of wording the questions in this manner may outweigh the costs. ${ }^{5}$

Most of the victims of sexual advantage are females, and most of the perpetrators are males. The sample size for the sexual advantage outcome is much smaller than the sample sizes for the other three outcomes because the question was asked exactly as it appears in Table 1 in 1989. In 1991 taking advantage of another person sexually and being taken advantage of sexually by another person were reported as separate items. In 1990 approximately 11 percent of the sample were asked the new question, while the rest were asked the old question. The data that we received from the Core Institute did not contain the responses to the old question. For 1990 and 1991 we created a single indicator of sexual advantage that equals one if at least one of the two separate indicators equals one. Note that gender-specific regressions did not indicate 
differences in slope coefficients.

Alcohol consumption is given by the average number of drinks consumed in a week. The mean value is 4.75 drinks per week and 7.92 drinks per week for the 60 percent of the sample that reported a positive number of drinks per week. This figure does not imply that 40 percent of the sample were abstainers because roughly 85 percent of the students consumed alcohol in the past year. These numbers suggest that 25 percent of the respondents consumed some alcohol in the past year but less than one drink per week. ${ }^{6}$

Alcohol consumption in the Core also can be measured by the incidence of binge drinking in the past two weeks (consumption of five or more drinks in a row) and by the number of such occasions. Forty percent of students engage in this behavior. The mean number of occasions is 1.28 for the whole sample and 3.19 for bingers. The incidence of binge drinking and the number of occasions are highly correlated with the number of drinks per week $(r=0.530$ and $r=0.734$, respectively). We do not use them as alternative measures of consumption because the violence outcomes pertain to the past year. Preliminary estimates that did employ them were very similar to the results presented in Section IV.

Student characteristics employed as independent variables in the regressions include age; class year (sophomore, junior, senior, graduate student, or non-matriculated student); race/ethnicity (black non-Hispanic, Hispanic, or other); gender; marital status (married or divorced); part-time student status; work status (full-time or part-time); and type of residence (on-campus housing but not in a fraternity or sorority, fraternity/sorority, or on-campus but type unknown). The only parental variables are indicators that the mother has alcohol/drug problems and that the father has alcohol/drug problems. ${ }^{7}$ Finally, all models include dichotomous variables for the years 1990 and 1991. 
The price of alcohol is given by the real price of beer in 1982-84 dollars in the state in which the college is located. The price of beer is selected because beer is the most heavily consumed alcoholic beverage and because beer is the beverage of choice among college students. The money price of beer is taken from the Inter-City Cost of Living Index, published quarterly by the American Chamber of Commerce Researchers Association (ACCRA various years) for between 250 and 300 cities. The specific beer price collected by ACCRA is the price of a sixpack (six-12 ounce cans) of Budweiser or Miller Light. ${ }^{8}$ In addition to obtaining information on the prices of a variety of consumer goods, the ACCRA constructs a city-specific cost of living for each city with an average for all cities in a given quarter and year equal to one.

The Core Surveys were conducted during the fall semesters of 1989, 1990, and 1991. Since the violence outcomes pertain to the previous year, the beer price in the survey year is given as a four-quarter average of the prices in the first two quarters of the survey year and the last two quarters of the previous year. Before averaging, each quarterly price is converted to a real price by dividing it by a quarter- and city-specific cost of living index. This index is the ACCRA city-specific cost of living index multiplied by the quarterly Bureau of Labor Statistics' CPI for the U.S. as a whole $(1982-84=1)$. Quarterly state prices are then computed as population weighted averages of city prices, and annual prices are obtained by averaging these prices over the four relevant quarters.

In interpreting the results in Section IV, one should bear in mind that the real price of beer is subject to measurement error for a variety of reasons. The price data pertain to the state in which the respondent attends college rather than to the city in which the college is located. In addition, the cost of living index reflects expenditure patterns of midmanagement (middleincome) households. These patterns may differ from those of college students. Random 
measurement error in an independent variable biases its coefficient and t-ratio toward zero.

Thus, the price coefficients and associated t-ratios in Section IV are conservative lower-bound estimates. With regard to the t-ratios, a factor that goes in the opposite direction is that conventional standard errors on which they are based do not take account of possible correlations among disturbances terms of students in the same college. Given positive correlations in these disturbance terms, t-ratios based on robust or Huber (1967) standard errors are smaller than the conventional or unadjusted t-ratios. If there is no measurement error in price and positive correlations among disturbance terms, unadjusted t-ratios are overstated, but this is not necessarily the case in the presence of measurement error.

We report both conventional and Huber t-ratios in the tables in the next section. In computing the latter, we use the college as the grouping factor. In the text we use conventional tratios in assessing statistical significance because we think that measurement error in the price is an important phenomenon. We realize, however, that the reader's views of this issue may differ from ours and provide enough information to allow him or her to evaluate significance based on Huber t-ratios.

Several other state-specific variables are included in some of the regression models. State real per capita income in 1982-84 dollars is a proxy for the student's income or his or her family income. If alcohol consumption or excessive consumption has a positive income elasticity, an increase in income should lead to more violence. A factor that goes in the opposite direction is that income may be positively correlated with the opportunity cost of the time spent in violence. Money per capita income by state is taken from the Bureau of Economic Analysis (various years). It is deflated by a state- and year-specific cost of living index obtained by multiplying the quarterly ACCRA cost of living index multiplied by the CPI for the U.S., 
obtaining population weighted averages at the state level, and then averaging over the four relevant quarters.

The per capita number of outlets that are licensed to sell alcoholic beverages for consumption on the premises, off the premises, or on and off the premises is a negative correlate of the amount of travel time required to purchase alcohol and should have positive effects on consumption and violence. The measure pertains to 1992 and is taken from Jobson Publishing Corporation (1993).

Violent behavior may depend on the use of illegal drugs as well as on the use of alcohol. The nature of the relationship, however, is ambiguous for reasons discussed in Markowitz and Grossman $(1998,1999)$. Since we focus on reduced form violence equations, illegal drug prices rather than quantities are the relevant regressors. ${ }^{9}$ Between 1976 and 1978, eleven states decriminalized the possession of small amounts of marijuana. This results in a lower full price of consuming marijuana in these states. We include a dichotomous variable that identifies students who attend colleges in these states. The sign of the coefficient of this variable is ambiguous. It depends on whether alcohol and marijuana are substitutes or complements. It also depends on the sign of the effect of marijuana consumption on violence and, if the effect is positive, on its magnitude relative to the magnitude of the alcohol effect. The decriminalization indicator is taken from the Bureau of Justice Statistics (1985).

To take account of the potential role of "drinking sentiment" in the endogenous determination of alcoholic beverage prices, alcohol consumption, and violence, the percentages of the state population who are Mormons, Southern Baptists, Catholics, Protestants (excluding Mormons and Southern Baptists), and Jewish are included in one specification of the model. The omitted category pertains to the percentage of the population with no religion. Drinking 
sentiment refers to cultural and taste factors that may either encourage or discourage alcohol consumption. For example, antidrinking sentiment should be relatively widespread in states in which those religious groups that oppose the use of alcohol, such as Mormons and Southern Baptists, are prevalent. These states may enact high excise tax rates on beer as part of the political process. In this situation the price coefficients that emerge from regressions that omit drinking sentiment overstate in absolute value the true parameters. ${ }^{10}$

For several reasons, caution should be exercised in interpreting the regressions that include the religion variables. First, our estimates pertain to college students who may play a much smaller role in the political process determining prices and taxes than older adults. Second, an individual's drinking sentiment is the key measure that determines his or her consumption of alcohol. With this variable held constant, there is little reason why state sentiment should have an impact on consumption. A student's sentiment towards alcohol may be reflected quite well by the decision to live in a fraternity/sorority and by parental alcohol behavior. Thus, the price effects are not necessarily biased by the omission of the religion variable. $^{11}$

For 1990 the religion variables except for the percentage Jewish are taken from Bradley et al. (1992). For 1989 and 1991, they are taken from interpolations and extrapolations of statespecific logarithmic time trends between 1980 and 1990. The 1980 data are reported by Quinn et al. (1982). The percentage Jewish is taken from the Bureau of Economic Analysis (various years).

\section{Empirical Results}

Table 2 contains reduced form violence regressions for the probability of getting into trouble with the police, residence hall, or other college authorities (trouble) and for the 
probability of damaging property, pulling a fire alarm, etc. (damage). Table 3 contains similar regressions for the probability of an argument or fight (fight) and for the probability of having been taken advantage of sexually or having taken advantage of another person sexually (termed sexual advantage). Table 4 contains reduced form demand functions for the number of drinks of alcohol in a week. Three models are estimated for each of these five outcomes. In the first model, the only state-specific variable is the real beer price. In the second, real per capita income and the per capita number of outlets that are licensed to sell alcohol are added as regressors. In the third, the five religion measures are included.

The most important result in these three tables is that the beer price coefficients are always negative and are significant in 14 of the 15 regressions. The only exception pertains to the sexual advantage regression that includes the religion variables. This finding is consistent with the hypothesis that an increase in the cost of alcohol lowers violence because it lowers alcohol consumption. The beer price effects are reduced in absolute value when the other statespecific variables are included. In general these reductions are largest when the religion variables are employed as regressors. The ratio of the price coefficient in model 1 to the corresponding coefficient in model 3 is 1.04 for trouble, 1.64 for damage, 1.29 for fight, 7.75 for sexual advantage, and 1.25 for the number of drinks.

The coefficient of real per capita income is positive in all models except when damage is the outcome and the religion variables are held constant and significant except in the damage equations. The coefficient of the number of licensed outlets is positive except when trouble is the outcome and the religion variables are not held constant and is significant in each case in which it is positive except in the trouble equation. There is little evidence that marijuana decriminalization has an impact on violence or alcohol consumption. 
The effects of the religion variables do not show a consistent pattern and are difficult to interpret. For example, an increase in the percentage of the population who are Mormons or Southern Baptists increases alcohol consumption rather than reduces it. The coefficients of these two variables do not have stable signs in the violence equations. The Mormon coefficient is positive in the trouble regression and negative in the damage, fight and sexual advantage regression. The Southern Baptist coefficient is negative except when fight is the outcome. The Protestant and Catholic coefficients are consistently positive and significant, but it is not clear whether these are true effects or effects of variables correlated with these two measures. The Jewish measure is usually positive and insignificant. On balance, we prefer the models that exclude the religion variables. We realize, however, that the reader may have different views on this issue, and we give equal weight to models that include and exclude the religion variables in summarizing the magnitudes of the price effects below.

Many of the student characteristics are important determinants of alcohol consumption and violence. We want to call attention to the differentials associated with living in a fraternity/sorority or in having a mother or father with alcohol/drug problems. Students who reside in a fraternity/sorority have approximately 6 more drinks per week than students who live off-campus and have approximately 5 more drinks per week than students who reside in a dormitory. The presence of a mother with alcohol/drug problems is associated with 1 extra drink per week and the presence of a father is associated with slightly more than one-half extra drink per week. The coefficients of these three variables always are positive and significant in the violence equations.

Table 5 contains price, income, and outlet elasticities of the five outcomes considered in Tables 2, 3, and 4 at the sample means. The price elasticity of the number of drinks of alcohol 
ranges between -0.74 and -0.98 with a mean of $-0.89 .^{12}$ This estimate is in the range of those in the published literature for young adults. Grossman, Chaloupka, and Sirtalan (1998) report a price elasticity of -0.65 for the number of drinks in the past year for persons between the ages of 19 and 27, not all of whom are in college. ${ }^{13}$ Kenkel (1993) estimates a price elasticity of -2.24 for the number of days in the past year on which a person between the ages of 18 and 21 had five or more drinks. ${ }^{14}$ Our income elasticity of the number of drinks of 0.63 is substantial, but the income measure employed in the regressions may be a poor proxy for the student's command of resources. The outlet elasticity of alcohol consumption of 0.33 is much smaller than the price or income elasticities.

The elasticity of each of the four violence outcomes with respect to the beer price is -0.48 for trouble, -0.52 for damage, -0.33 for fight, and -0.36 . for sexual advantage. Consider an exactly identified model in which the beer price is the only variable omitted from the structural violence equation. In this model, the implied elasticity of violence with respect to alcohol consumption is 0.54 for trouble, 0.58 for damage, 0.37 for fight, and 0.40 for sexual advantage.

Table 6 contains actual estimates of structural violence equations by two-stage least squares for trouble and damage, and Table 7 contains similar estimates for fight and sexual advantage. The number of drinks of alcohol is treated as an endogenous variable in these estimates. The three models for each outcome correspond to the three models in Tables 2 and 3. In model 1 the beer price is the only instrument for alcohol consumption (the only variable included in the first stage but excluded from the second stage). In models 2 and 3 , the instruments are the beer price and the number of outlets. The treatment of income is somewhat controversial. If income affects violence solely through alcohol consumption, it should be excluded from the second stage. We include it to capture omitted endogenous and exogenous 
factors that may determine violence. Similar comments can be made with regard to such student characteristics as residence in a fraternity/sorority and the presence of a parent with alcohol/drug problems.

Alcohol consumption has a positive and significant coefficient in all twelve models in Tables 6 and 7. According to the Wu (1973) F test, the consistency of ordinary least squares estimation of the structure is rejected in four cases but accepted in eight cases at the five percent level. Therefore, it is worth considering both the OLS and the TSLS elasticity of each of the violence outcomes with respect to alcohol consumption. These are shown in Table 8. The TSLS elasticity is 0.40 for trouble, 0.63 for damage, 0.39 for fight, and 0.33 for sexual abuse. The corresponding OLS elasticities are $0.48,0.58,0.27$, and 0.30 . These elasticities do not dramatically differ from each other or from those that are implied by the exactly identified model that was described above.

In summary our results are consistent with a causal mechanism in which the price of alcohol affects violence because it affects the consumption of alcohol. These results do not indicate whether violence is an anticipated or unanticipated consequence of alcohol consumption. They also do not indicate whether alcohol consumption is treated by students as an input to facilitate violent behavior or as an anticipated negative consequence that is outweighed by the positive benefits derived from its consumption. What they do suggest is that alcohol regulatory variables may influence the general level of violence 


\section{References}

American Chamber of Commerce Researchers Association. Inter-City Cost of Living Index. Louisville, Kentucky: ACCRA, various years.

Becker, Gary S.; Grossman, Michael; and Murphy, Kevin M. "Rational Addiction and the Effect of Price on Consumption.” American Economic Review, 81, No. 2 (May 1991), 237241.

Becker, Gary S., and Murphy, Kevin M. “A Theory of Rational Addiction.” Journal of Political Economy, 96, No. 4 (August 1988), 675-700.

Bradley, Martin R.; Green, Norman M., Jr.; Jones, Dale E.; Lynn, Mac; and McNeil, Lou. Churches and Church Membership in the United States 1990. Atlanta, Georgia: Glenmary Research Center, 1992.

Bureau of Economic Analysis, U.S. Department of Commerce. Survey of Current Business, various years.

Bureau of Justice Statistics, U.S. Department of Justice. Alcohol and Crime. NCJ-168632, April 1998.

Bureau of Justice Statistics, U.S. Department of Justice. Report to the Nation on Crime and Justice. Second Edition. NCJ-105506, March 1988.

Bureau of Justice Statistics, U.S. Department of Justice. Sourcebook of Criminal Justice Statistics 1984. Washington, D.C.: U.S. Government Printing Office, 1985.

Bureau of Justice Statistics, U.S. Department of Justice. Substance Abuse and Treatment, State and Federal Prisoners, 1997. NCJ-172871, January 1999.

Chaloupka, Frank J., and Wechsler, Henry. "Binge Drinking in College: The Impact of Price, Availability, and Alcohol Control Policies." Contemporary Economic Policy, 14, No. 4 
(October 1996), 112-124.

Chaloupka, Frank J., and Saffer, Henry. "Alcohol, Illegal Drugs, Public Policy, and Crime.” Presented at the annual meeting of the Western Economic Association, San Francisco, California, July 1992.

Chaloupka, Frank J.; Saffer, Henry; and Grossman, Michael. "Alcohol-Control Policies and Motor-Vehicle Fatalities.” Journal of Legal Studies, 22, No. 1 (January 1993), 161-186. Collins, James J., and Schlenger, William. "Acute and Chronic Effects of Alcohol Use on Violence. Journal of Studies on Alcohol, 49, No. 6 (1988), 516-521.

Cook, Phillip J., and Moore, Michael J. "Drinking and Schooling." Journal of Health Economics, 12, No. 4 (December 1993a), 411-430.

Cook, Phillip J., and Moore, Michael J. "Economic Perspectives on Reducing Alcohol-Related Violence.” In Alcohol and Interpersonal Violence: Fostering Multidisciplinary Perspectives, edited by Susan E. Martin. National Institute on Alcohol Abuse and Alcoholism Research Monograph 24. NIH Publication No. 93-3496. Washington, D.C.: U.S. Government Printing Office, 1993b, 193-211.

Cook, Philip J., and Tauchen, George. "The Effect of Liquor Taxes on Heavy Drinking.” Bell Journal of Economics, 13, No. 2 (Autumn 1982), 379-390.

Cordilia, Ann. "Alcohol and Property Crime: Exploring the Causal Nexus." Journal of Studies on Alcohol, 46, No. 2 (1985), 161- 171.

Fagan, Jeffrey. "Interactions among Drugs, Alcohol, and Violence." Health Affairs, 12, No. 4 (Winter 1993a), 65-79.

Fagan, Jeffrey. "Set and Setting Revisited: Influences of Alcohol and Illicit Drugs on the Social Context of Violent Events.” In Alcohol and Interpersonal Violence: Fostering 
Multidisciplinary Perspectives, edited by Susan E. Martin. National Institute on Alcohol Abuse and Alcoholism Research Monograph 24. NIH Publication No. 93-3496.

Washington, D.C.: U.S. Government Printing Office, 1993b, 161-192.

Gelles, Richard J., and Cornell, Claire P. Intimate Violence in Families. Newbury Park, California, 1990.

Goldstein, Paul J. "The Drugs/Violence Nexus: A Tripartite Conceptual Model.” Journal of Drug Issues, 15 (Fall 1985), 493-506.

Grossman, Michael; Chaloupka, Frank J.; and Sirtalan, Ismail. “An Empirical Analysis of Alcohol Addiction: Results from the Monitoring the Future Panels.” Economic Inquiry, 36, No. 1 (January 1998), 39-48.

Huber, Peter J. "The Behavior of Maximum Likelihood Estimates under Nonstandard Conditions.” In Fifth Berkeley Symposium on Mathematical Statistics and Probability. Berkeley, California: University of California Press, 1967, 221-233.

Jobson, Publishing Corporation. Licensed Beverage Marketing \& Merchandising Fact Book 1993. New York: Jobson Publishing Corporation, 1993.

Johnston, Lloyd D.; O'Malley, Patrick M.; and Bachman, Jerald G. National Survey Results on Drug Use from Monitoring the Future Study, 1975-1996. Rockville, Maryland: National Institute on Drug Abuse, 1997.

Kenkel, Donald S. "Drinking, Driving, and Deterrence: The Social Costs of Alternative Policies.” Journal of Law and Economics, 36, No. 2 (October 1993), 877-913.

Long, Sharon K., Witte, Ann D., and Karr, Patrice. "Family Violence: A Microeconomic Approach.” Social Science Research, 12 (1983), 363-392.

Markowitz, Sara, and Grossman, Michael. "Alcohol Regulation and Domestic Violence 
Towards Children.” Contemporary Economic Policy, 15, No. 3 (July 1998), 309-320.

Markowitz, Sara, and Grossman, Michael. “The Effects of Beer Taxes on Physical Child Abuse.” National Bureau of Economic Research Working Paper No. 6629, Revised February 1999.

Martin, Susan E., editor. Alcohol and Interpersonal Violence: Fostering Multidisciplinary

Perspectives. National Institute on Alcohol Abuse and Alcoholism Research Monograph 24. NIH Publication No. 93-3496. Washington, D.C.: U.S. Government Printing Office, 1993.

Pernanen, Kai. Alcohol in Human Violence. New York: Guilford Press, 1991.

Pernanen, Kai. "Alcohol-Related Violence: Conceptual Models and Methodological Issues." In

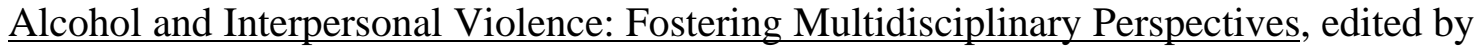
Susan E. Martin. National Institute on Alcohol Abuse and Alcoholism Research Monograph 24. NIH Publication No. 93-3496. Washington, D.C.: U.S. Government Printing Office, 1993, 37-70.

Pernanen, Kai. "Theoretical Aspects of the Relationship between Alcohol Use and Crime." In Drinking and Crime: Perspectives on the Relationship between Alcohol Consumption and Criminal Behavior, edited by James J. Collins. New York: Guilford Press, 1981, 1-69.

Presley, Cheryl A.; Meilman, Philip W.; and Lyerla, Rob. Alcohol and Drugs on American College Campuses. Volume I: 1989-91. Carbondale, Illinois: Southern Illinois University Core Institute, 1993.

Presley, Cheryl A.; Meilman, Philip W.; and Lyerla, Rob. Alcohol and Drugs on American College Campuses. Volume II: 1990-92. Carbondale, Illinois: Southern Illinois University Core Institute, 1995. 
Presley, Cheryl A.; Meilman, Philip W.; Cashin, Jeffrey R.; and Lyerla, Rob. Alcohol and Drugs on American College Campuses. Volume III: 1991-93. Carbondale, Illinois: Southern Illinois University Core Institute, 1996.

Quinn, Bernard; Anderson, Herman; Bradley, Martin; Goetting, Paul; and Shriver, Peggy. Churches and Church Membership in the United States 1980. Atlanta, Georgia: Glenmary Research Center, 1982.

Reiss, Albert J., Jr., and Roth, Jeffrey E., Editors. Understanding and Preventing Violence. Washington, D.C.: National Academy Press, 1993.

Ruhm, Christopher J. “Alcohol Policies and Highway Fatality Rates.” Journal of Health Economics, 15, No. 4 (August 1996), 435-454.

Saffer, Henry. "Alcohol Advertising Bans and Alcohol Abuse: An International Perspective." Journal of Health Economics, 10, No. 1 (May 1991), 65-79.

Saffer, Henry, and Grossman, Michael. "Beer Taxes, the Legal Drinking Age, and Youth Motor Vehicle Fatalities.” Journal of Legal Studies, 16, No. 2 (June 1987), 351-374.

Schelling, Thomas C. "Egonomics, or the Art of Self-Management." American Economic Review, 68, No. 2 (May 1978), 291-294.

Sloan, Frank A.; Reilly, Bridget A.; and Schenzler, Christopher. "Effects of Tort Liability and Insurance on Heavy Drinking and Drinking and Driving.” Journal of Law and Economics, 38, No. 1 (April 1995), 49-78.

Tauchen, Helen V.; Witte, Ann Dryden; and Long, Sharon K. "Domestic Violence: A Nonrandom Affair.” International Economic Review, 32, No. 2 (May 1991), 491-511. Thaler, Richard H., and Shefrin, H. M. “An Economic Theory of Self-Control.” Journal of Political Economy, 89, No. 2 (April 1981), 392-406. 
Viscusi, W. Kip. "Market Incentives for Criminal Behavior." In The Black Youth Employment Crisis, edited by Richard B. Freeman and Henry J. Holzer. Chicago: University of Chicago Press, 1986, 301-346.

Wolfgang, Marvin E. Patterns in Criminal Behavior. New York: John Wiley and Sons, 1958.

Wu, De-Min. "Alternative Tests of Independence Between Stochastic Regressors and

Disturbances." Econometrica 41, No. 4 (July 1973), 733-750. 


\section{Footnotes}

This paper was presented at a session entitled Economic Aspects of Substance Use and Abuse at the Taipei International Conference on Health Economics organized by the Institute of Economics, Academia Sinica in Taipei, Taiwan, March 25-26, 1999. A preliminary version of the paper was presented at the 1998 meeting of the American Economic Association. Research for the paper was supported by grant number 1 R01 AA10817 from the National Institute on Alcohol Abuse and Alcoholism to the National Bureau of Economic Research. We are indebted to Rob Lyerla, formerly Assistant Director of the Core Institute of Southern Illinois University, for giving us permission to acquire the Core Surveys with state identifiers and to Jeffrey R. Cashin, currently Assistant Director of the Core Institute, for creating our data diskettes. We also are indebted to Philip J. Cook, Andrew M. Jones, Donald S. Kenkel, Henry Saffer, and participants of the two conferences at which the paper was presented for helpful comments and suggestions. This paper has not undergone the review accorded official NBER publications; in particular, it has not been submitted for approval by the Board of Directors. Any opinions expressed are those of the authors and not those of NIAAA or NBER.

${ }^{1}$ If the consequences are anticipated and have monetary penalties, the quantity of alcohol demand and the amount of violence depend on these penalties as well as on the price of alcohol. A model in which violence is a positive source of utility formalizes the notion that the decision to engage in violent acts can stimulate alcohol consumption because consumption raises productivity or lowers the cost of violence. Here we assume that violence is produced by two endogenous inputs: alcohol consumption and the own time of the perpetrator. For more details, see Markowitz and Grossman (1998, 1999). 
${ }^{2}$ The states included are Alaska, California, Colorado, Connecticut, Florida, Georgia, Illinois, Indiana, Iowa, Louisiana, Maryland, Massachusetts, Michigan, Minnesota, Missouri, Montana, Nebraska, New Hampshire, New York, North Carolina, Ohio, Oregon, Pennsylvania, South Carolina, Texas, Utah, Virginia, Washington, and West Virginia. Maine and New Jersey are omitted because the price of beer was missing for these two states in 1989.

${ }^{3}$ Given the large sample size, little is gained by fitting logit or probit models. The number of occasions of each type of violence in the past year also is reported, but we have not yet exploited this information.

${ }^{4}$ Each rate was computed after deleting observations with missing values. The same comment applies to the mean value of the number of drinks of alcohol in a week in Table 1.

${ }^{5}$ One caveat to the above argument pertains to a situation in which violence that does not involve alcohol is positively related to the price of alcohol. This case is extremely unlikely. If, however, it does occur, price may have no effect on all types of violence even if it has a negative effect on alcohol-related violence. The more likely case is the one that we implicitly assume: no relationship between price and violence not involving alcohol.

${ }^{6}$ Respondents could not indicate that they consumed alcohol but consumed less than one drink per week in answering the question pertaining to drinks per week.

${ }^{7}$ Except for type of residence, the small number of missing values for the variables just listed are replaced by sample means. A change in the questions determining type of residence between 1989 and 1990 generated a large number of cases in which a student lived on-campus, but it could not be determined whether the residence was a dormitory or a fraternity/sorority.

${ }^{8}$ Prior to the fourth quarter of 1989 , the brands of beer were Budweiser and Schlitz. 
Prices for quarters prior to the fourth quarter of 1989 were adjusted based on the trend in the mean ACCRA beer price for the U.S. as a whole between the third and fourth quarters of 1989 relative to the trend in the U.S. beer price index reported by the Bureau of Labor Statistics.

${ }^{9}$ The Core Surveys contain information on the use of marijuana, cocaine, and other illegal drugs. They are relevant endogenous regressors in the structural violence equation, but we have not yet exploited these variables.

${ }^{10}$ The bias could go in the other direction if states in which prodrinking sentiment is widespread (antidrinking sentiment is weak) and alcohol consumption is large enact higher beer taxes because the taxation of beer is an attractive source of revenue.

${ }^{11}$ We limit the number of state-specific regressors because Markowitz and Grossman $(1998,1999)$ report that such additional determinants of alcohol consumption and violence as restrictions on alcohol advertising, permission of beer sales by grocery stores, the percentage of the state's population residing in counties that prohibit the sale of alcohol, and the price of cocaine have little impact on the outcomes they consider. Clearly, measures that vary by state alone are likely to be collinear. Thus, the degree of multicollinearity in the data is reduced by curtailing the number of state-specific regressors.

${ }^{12}$ In the remainder of this section, all elasticities mentioned in the text are averages of those that emerge from the three alternative models employed for a given dependent variable.

${ }^{13}$ Grossman, Chaloupka, and Sirtalan's indicator of the number of drinks in the past year is measured subject to error because it is computed as the product of the number of drinking occasions in the past year and the number of drinks consumed on typical occasion. The latter is inferred from the response to a question concerning how often the respondent drinks enough to 
feel pretty high. For this reason and others, their dependent variable is not entirely comparable to our dependent variable.

${ }^{14}$ This is an average of the separate estimates that Kenkel reports for males and females. When we employ the number of days in the past two weeks on which an individual consumed five or more drinks in a row as an outcome, we obtain a price elasticity of -0.78 . 
Table 1

Definitions, Means and Standard Deviations of Variables ( $n=120,864$ except where otherwise indicated)

\begin{tabular}{|c|c|c|}
\hline Variable & Definition & Mean, Standard Deviation \\
\hline Trouble $^{\mathrm{a}}$ & $\begin{array}{l}\text { Dichotomous variable that equals } 1 \text { if } \\
\text { respondent had been in trouble with } \\
\text { police, residence hall or other college } \\
\text { authorities due to drinking or drug use in } \\
\text { the past year }\end{array}$ & $\begin{array}{l}0.123,0.329 \\
(\mathrm{n}=115,752)\end{array}$ \\
\hline Damage $^{a}$ & $\begin{array}{l}\text { Dichotomous variable that equals } 1 \text { if } \\
\text { respondent had damaged property, } \\
\text { pulled fire alarm, etc. due to drinking or } \\
\text { drug use in the past year }\end{array}$ & $\begin{array}{l}0.075,0.264 \\
(n=115,471)\end{array}$ \\
\hline Fight $^{\mathrm{a}}$ & $\begin{array}{l}\text { Dichotomous variable that equals } 1 \text { if } \\
\text { respondent got into an argument or fight } \\
\text { due to drinking or drug use in the past } \\
\text { year }\end{array}$ & $\begin{array}{l}0.312,0.463 \\
(\mathrm{n}=115,061)\end{array}$ \\
\hline Sexual advantage ${ }^{a}$ & $\begin{array}{l}\text { Dichotomous variable that equals } 1 \text { if } \\
\text { respondent had been taken advantage of } \\
\text { sexually or had taken advantage of } \\
\text { another sexually due to drinking or drug } \\
\text { use in the past year }\end{array}$ & $\begin{array}{c}0.143,0.350 \\
(n=86,801)\end{array}$ \\
\hline Number of drinks ${ }^{a}$ & $\begin{array}{l}\text { Average number of drinks consumed in a } \\
\text { week. (A drink is a bottle of beer, a } \\
\text { glass of wine, a wine cooler, a shot glass } \\
\text { of liquor or a mixed drink) }\end{array}$ & $\begin{array}{l}4.709,8.734 \\
(\mathrm{n}=118,177)\end{array}$ \\
\hline Real beer price & $\begin{array}{l}\text { Real annual beer price in } 1982-1984 \\
\text { dollars }\end{array}$ & $2.488,0.219$ \\
\hline Real income & State real per capita income & $10079.710,1048.430$ \\
\hline Number of licensed outlets per capita & $\begin{array}{l}\text { State per capital number of retail outlets } \\
\text { licensed to sell beer, wine or spirits in a } \\
\text { state }\end{array}$ & $0.002,0.001$ \\
\hline Marijuana decriminalization & $\begin{array}{l}\text { Dichotomous variable that equals } 1 \text { if } \\
\text { respondent resides in a state in which } \\
\text { incarceration and heavy fines are not } \\
\text { penalties for most marijuana possession } \\
\text { offenses }\end{array}$ & $0.432,0.495$ \\
\hline Mormon & $\begin{array}{l}\text { Percentage of the state population who } \\
\text { are Mormon }\end{array}$ & $1.839,8.189$ \\
\hline Southern Baptist & $\begin{array}{l}\text { Percentage of the state population who } \\
\text { are Southern Baptist }\end{array}$ & $3.984,6.251$ \\
\hline Protestant & $\begin{array}{l}\text { Percentage of the state population who } \\
\text { are Protestant }\end{array}$ & $21.028,9.125$ \\
\hline Catholic & $\begin{array}{l}\text { Percentage of the state population who } \\
\text { are Catholic }\end{array}$ & $22.255,12.182$ \\
\hline Jewish & $\begin{array}{l}\text { Percentage of the state population who } \\
\text { are Jewish }\end{array}$ & $2.392,2.619$ \\
\hline Age & Respondent's age & $22.913,6.935$ \\
\hline Sophomore & $\begin{array}{l}\text { Dichotomous variable that equals } 1 \text { if } \\
\text { respondent is a sophomore }\end{array}$ & $0.229,0.417$ \\
\hline
\end{tabular}


Junior

Senior

Graduate student

Non-matriculated

Black

Hispanic

Other race

Female

Married

Divorced

Part-time student

Works full-time

Works part-time

Lives in on-campus housing

Lives in a fraternity/sorority

On campus residence unknown

Mother has alcohol/drug problems

Father has alcohol/drug problems

1990

1991
Dichotomous variable that equals 1 if respondent is a junior

Dichotomous variable that equals 1 if respondent is a senior

Dichotomous variable that equals 1 if respondent is seeking a graduate or professional degree

Dichotomous variable that equals 1 if respondent is not seeking a degree

Dichotomous variable that equals 1 if respondent is black, non-Hispanic

Dichotomous variable that equals 1 if respondent is Hispanic

Dichotomous variable that equals 1 if respondent is of another race/ethnicity

Dichotomous variable that equals 1 if respondent is female

Dichotomous variable that equals 1 if respondent is married

Dichotomous variable that equals 1 if respondent is divorced

Dichotomous variable that equals 1 if respondent attends school part-time

Dichotomous variable that equals 1 if respondent works full-time

Dichotomous variable that equals 1 if respondent works part-time

Dichotomous variable that equals 1 if respondent lives in on-campus housing

Dichotomous variable that equals 1 if respondent lives in a fraternity or sorority

Dichotomous variable that equals 1 if respondent lives in on-campus housing, but type of housing is unknown

Dichotomous variable that equals 1 if respondent's mother had alcohol or drug problems

Dichotomous variable that equals 1 if respondent's father had alcohol or drug problems

Dichotomous indicator for survey year 1990

Dichotomous indicator for survey year 1991
$0.186,0.385$

$0.181,0.382$

$0.058,0.232$

$0.027,0.160$

$0.050,0.215$

$0.048,0.210$

$0.076,0.261$

$0.589,0.473$

$0.134,0.339$

$0.042,0.199$

$0.140,0.343$

$0.134,0.336$

$0.460,0.492$

$0.357,0.479$

0.017, 0.131

$0.210,0.407$

$0.054,0.227$

$0.159,0.366$

$0.271,0.445$

$0.261,0.439$

${ }^{\mathrm{a}}$ Mean and standard deviation based on a sample that excludes unknown values. 
Table 2

Reduced Form Violence Estimates ${ }^{\mathrm{a}}$

\begin{tabular}{|c|c|c|c|c|c|c|}
\hline & \multicolumn{3}{|c|}{$\begin{array}{c}\text { Trouble } \\
(\mathrm{n}=115,752)\end{array}$} & \multicolumn{3}{|c|}{$\begin{array}{c}\text { Damage } \\
(\mathrm{n}=115,471)\end{array}$} \\
\hline & (1) & (2) & (3) & (1) & (2) & (3) \\
\hline Real beer price & $\begin{array}{c}-0.025 \\
(-5.48) \\
{[-1.28]}\end{array}$ & $\begin{array}{l}-0.023 \\
(-4.93) \\
{[-1.10]}\end{array}$ & $\begin{array}{c}-0.024 \\
(-4.34) \\
{[-1.00]}\end{array}$ & $\begin{array}{c}-0.018 \\
(-4.91) \\
{[-2.07]}\end{array}$ & $\begin{array}{c}-0.019 \\
(-5.12) \\
{[-2.19]}\end{array}$ & $\begin{array}{l}-0.011 \\
(-2.45) \\
{[-0.97]}\end{array}$ \\
\hline Real income & & $\begin{array}{l}0.00001 \\
(7.87) \\
{[2.42]}\end{array}$ & $\begin{array}{l}0.00001 \\
(4.22) \\
{[1.39]}\end{array}$ & & $\begin{array}{l}0.000001 \\
(0.89) \\
{[0.36]}\end{array}$ & $\begin{array}{l}-0.0000002 \\
(-0.21) \\
{[-0.10]}\end{array}$ \\
\hline $\begin{array}{l}\text { Number of licensed outlets per } \\
\text { capita }\end{array}$ & & $\begin{array}{c}0.107 \\
(0.08) \\
{[0.02]}\end{array}$ & $\begin{array}{c}6.509 \\
(3.62) \\
{[0.99]}\end{array}$ & & $\begin{array}{c}5.798 \\
(5.17) \\
{[2.01]}\end{array}$ & $\begin{array}{c}8.890 \\
(6.13) \\
{[2.76]}\end{array}$ \\
\hline Marijuana decriminalization & & $\begin{array}{l}0.0001 \\
(0.03) \\
{[0.01]}\end{array}$ & $\begin{array}{l}-0.001 \\
(-0.40) \\
{[-0.11]}\end{array}$ & & $\begin{array}{c}0.002 \\
(1.28) \\
{[0.51]}\end{array}$ & $\begin{array}{l}-0.0003 \\
(-0.19) \\
{[-0.09]}\end{array}$ \\
\hline Mormon & & & $\begin{array}{l}0.0001 \\
(0.69) \\
{[0.23]}\end{array}$ & & & $\begin{array}{l}-0.00003 \\
(-0.24) \\
{[-0.13]}\end{array}$ \\
\hline Southern Baptist & & & $\begin{array}{l}-0.001 \\
(-3.70) \\
{[-1.15]}\end{array}$ & & & $\begin{array}{l}-0.0001 \\
(-0.56) \\
{[-0.25]}\end{array}$ \\
\hline Protestant & & & $\begin{array}{c}0.001 \\
(7.68) \\
{[2.20]}\end{array}$ & & & $\begin{array}{c}0.001 \\
(5.62) \\
{[2.36]}\end{array}$ \\
\hline Catholic & & & $\begin{array}{c}0.001 \\
(8.93) \\
{[2.23]}\end{array}$ & & & $\begin{array}{c}0.001 \\
(8.20) \\
{[3.06]}\end{array}$ \\
\hline Jewish & & & $\begin{array}{l}-0.003 \\
(-5.77) \\
{[-1.36]}\end{array}$ & & & $\begin{array}{c}0.001 \\
(1.36) \\
{[0.54]}\end{array}$ \\
\hline Age & $\begin{array}{r}-0.003 \\
(-13.62) \\
{[-13.71]}\end{array}$ & $\begin{array}{r}-0.003 \\
(-13.86) \\
{[-13.91]}\end{array}$ & $\begin{array}{r}-0.003 \\
(-14.00) \\
{[-14.24]}\end{array}$ & $\begin{array}{r}-0.002 \\
(-12.80) \\
{[-11.63]}\end{array}$ & $\begin{array}{c}-0.002 \\
(-12.74) \\
{[-11.87]}\end{array}$ & $\begin{array}{c}-0.002 \\
(-12.74) \\
{[-12.14]}\end{array}$ \\
\hline Sophomore & $\begin{array}{c}0.002 \\
(0.68) \\
{[0.40]}\end{array}$ & $\begin{array}{c}0.001 \\
(0.57) \\
{[0.34]}\end{array}$ & $\begin{array}{c}0.002 \\
(0.90) \\
{[0.57]}\end{array}$ & $\begin{array}{l}-0.001 \\
(-0.60) \\
{[-0.44]}\end{array}$ & $\begin{array}{l}-0.001 \\
(-0.37) \\
{[-0.28]}\end{array}$ & $\begin{array}{l}-0.0001 \\
(-0.06) \\
{[-0.05]}\end{array}$ \\
\hline Junior & $\begin{array}{l}-0.009 \\
(-3.32) \\
{[-2.06]}\end{array}$ & $\begin{array}{l}-0.010 \\
(-3.60) \\
{[-2.27]}\end{array}$ & $\begin{array}{l}-0.011 \\
(-3.97) \\
{[-2.57]}\end{array}$ & $\begin{array}{l}-0.002 \\
(-0.93) \\
{[-0.65]}\end{array}$ & $\begin{array}{l}-0.002 \\
(-0.71) \\
{[-0.51]}\end{array}$ & $\begin{array}{l}-0.002 \\
(-0.93) \\
{[-0.68]}\end{array}$ \\
\hline Senior & $\begin{array}{r}-0.032 \\
(-10.82) \\
{[-6.44]}\end{array}$ & $\begin{array}{r}-0.032 \\
(-10.94) \\
{[-6.35]}\end{array}$ & $\begin{array}{r}-0.034 \\
(-11.45) \\
{[-6.73]}\end{array}$ & $\begin{array}{l}-0.011 \\
(-4.65) \\
{[-2.76]}\end{array}$ & $\begin{array}{l}-0.011 \\
(-4.48) \\
{[-2.71]}\end{array}$ & $\begin{array}{l}-0.012 \\
(-4.99) \\
{[-3.14]}\end{array}$ \\
\hline Graduate student & $\begin{array}{r}-0.052 \\
(-11.14) \\
{[-7.56]}\end{array}$ & $\begin{array}{r}-0.054 \\
(-11.57) \\
{[-7.83]}\end{array}$ & $\begin{array}{r}-0.051 \\
--10.81) \\
{[-6.82]}\end{array}$ & $\begin{array}{l}-0.026 \\
(-6.96) \\
{[-5.49]}\end{array}$ & $\begin{array}{l}-0.026 \\
(-6.91) \\
{[-5.22]}\end{array}$ & $\begin{array}{l}-0.024 \\
(-6.51) \\
{[-4.71]}\end{array}$ \\
\hline Non-matriculated & $\begin{array}{l}-0.010 \\
(-1.54) \\
{[-1.76]}\end{array}$ & $\begin{array}{l}-0.012 \\
(-1.80) \\
{[-2.06]}\end{array}$ & $\begin{array}{l}-0.010 \\
(-1.53) \\
{[-1.64]}\end{array}$ & $\begin{array}{c}0.002 \\
(0.47) \\
{[0.49]}\end{array}$ & $\begin{array}{c}0.002 \\
(0.45) \\
{[0.49]}\end{array}$ & $\begin{array}{c}0.002 \\
(0.45) \\
{[0.49]}\end{array}$ \\
\hline Black & $\begin{array}{c}-0.076 \\
(-17.23) \\
{[-12.98]}\end{array}$ & $\begin{array}{r}-0.075 \\
(-16.92) \\
{[-12.46]}\end{array}$ & $\begin{array}{r}-0.071 \\
(-16.05) \\
{[-11.85]}\end{array}$ & $\begin{array}{c}-0.047 \\
(-13.34) \\
{[-14.11]}\end{array}$ & $\begin{array}{r}-0.049 \\
(-13.89) \\
{[-13.48]}\end{array}$ & $\begin{array}{c}-0.048 \\
(-13.38) \\
{[-13.34]}\end{array}$ \\
\hline
\end{tabular}


Table 2 (continued)

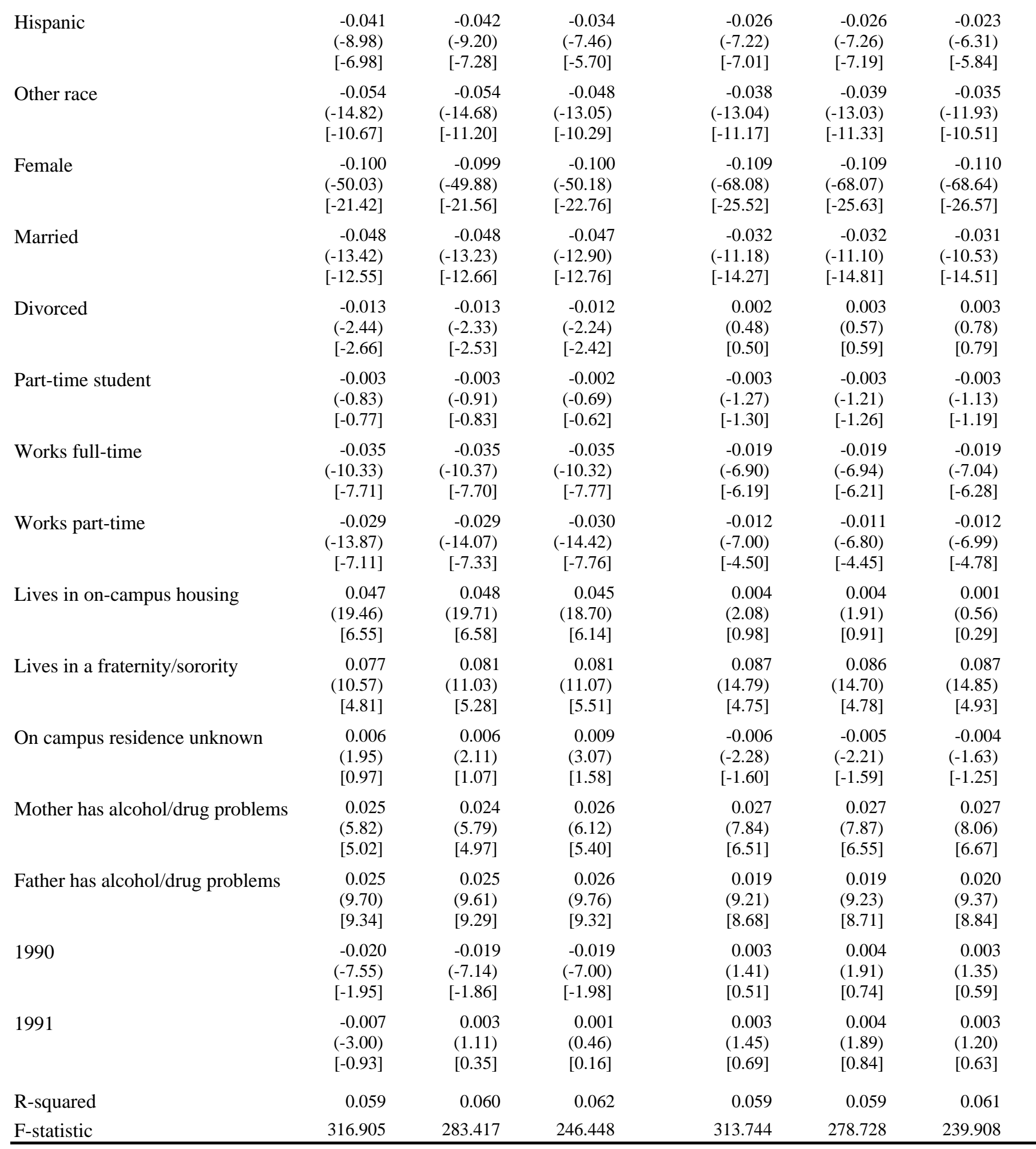

\footnotetext{
${ }^{a}$ t-statistics in parentheses, Huber t-statistics in brackets, and intercepts not shown.
} 
Table 3

Reduced Form Violence Estimates ${ }^{\mathrm{a}}$

\begin{tabular}{|c|c|c|c|c|c|c|}
\hline & \multicolumn{3}{|c|}{$\begin{array}{c}\text { Fight } \\
(\mathrm{n}=115,061)\end{array}$} & \multicolumn{3}{|c|}{$\begin{array}{c}\text { Sexual Advantage } \\
(\mathrm{n}=86,801)\end{array}$} \\
\hline & (1) & (2) & (3) & (1) & (2) & (3) \\
\hline Real beer price & $\begin{array}{c}-0.045 \\
(-7.08) \\
{[-1.61]}\end{array}$ & $\begin{array}{l}-0.045 \\
(-7.00) \\
{[-1.64]}\end{array}$ & $\begin{array}{l}-0.035 \\
(-4.59) \\
{[-1.02]}\end{array}$ & $\begin{array}{c}-0.031 \\
(-5.59) \\
{[-2.72]}\end{array}$ & $\begin{array}{c}-0.028 \\
(-4.97) \\
{[-2.42]}\end{array}$ & $\begin{array}{c}-0.004 \\
(-0.63) \\
{[-0.33]}\end{array}$ \\
\hline Real income & & $\begin{array}{l}0.00001 \\
(9.13) \\
{[2.19]}\end{array}$ & $\begin{array}{l}0.00001 \\
(5.65) \\
{[1.65]}\end{array}$ & & $\begin{array}{l}0.000004 \\
(2.78) \\
{[1.23]}\end{array}$ & $\begin{array}{l}0.00001 \\
(3.45) \\
{[2.07]}\end{array}$ \\
\hline $\begin{array}{l}\text { Number of licensed outlets per } \\
\text { capita }\end{array}$ & & $\begin{array}{l}15.252 \\
(7.77) \\
{[1.51]}\end{array}$ & $\begin{array}{l}21.198 \\
(8.36) \\
{[2.09]}\end{array}$ & & $\begin{array}{l}1.735 \\
(1.04) \\
{[0.46]}\end{array}$ & $\begin{array}{l}7.102 \\
(3.16) \\
{[1.71]}\end{array}$ \\
\hline Marijuana decriminalization & & $\begin{array}{c}0.004 \\
(1.50) \\
{[0.35]}\end{array}$ & $\begin{array}{l}-0.002 \\
(-0.70) \\
{[-0.19]}\end{array}$ & & $\begin{array}{c}0.004 \\
(1.72) \\
{[0.78]}\end{array}$ & $\begin{array}{c}-0.004 \\
(-1.35) \\
{[-0.73]}\end{array}$ \\
\hline Mormon & & & $\begin{array}{l}-0.0003 \\
(-1.18) \\
{[-0.34]}\end{array}$ & & & $\begin{array}{l}-0.0001 \\
(-0.56) \\
{[-0.43]}\end{array}$ \\
\hline Southern Baptist & & & $\begin{array}{l}0.0001 \\
(0.29) \\
{[0.07]}\end{array}$ & & & $\begin{array}{l}-0.001 \\
(-3.01) \\
{[-1.65]}\end{array}$ \\
\hline Protestant & & & $\begin{array}{r}0.002 \\
(11.11) \\
{[2.64]}\end{array}$ & & & $\begin{array}{c}0.001 \\
(3.80) \\
{[1.97]}\end{array}$ \\
\hline Catholic & & & $\begin{array}{r}0.002 \\
(13.41) \\
{[2.72]}\end{array}$ & & & $\begin{array}{c}0.001 \\
(3.20) \\
{[1.97]}\end{array}$ \\
\hline Jewish & & & $\begin{array}{l}0.0004 \\
(0.56) \\
{[0.14]}\end{array}$ & & & $\begin{array}{c}0.003 \\
(4.70) \\
{[2.02]}\end{array}$ \\
\hline Age & $\begin{array}{r}-0.009 \\
(-29.94) \\
{[-25.43]}\end{array}$ & $\begin{array}{r}-0.009 \\
(-30.09) \\
{[-25.64]}\end{array}$ & $\begin{array}{c}-0.009 \\
(-30.15) \\
{[-26.43]}\end{array}$ & $\begin{array}{r}-0.004 \\
(-14.09) \\
{[-13.33]}\end{array}$ & $\begin{array}{r}-0.004 \\
(-14.16) \\
{[-13.43]}\end{array}$ & $\begin{array}{r}-0.004 \\
(-14.20) \\
{[-13.45]}\end{array}$ \\
\hline Sophomore & $\begin{array}{c}0.006 \\
(1.55) \\
{[0.96]}\end{array}$ & $\begin{array}{c}0.007 \\
(1.78) \\
{[1.11]}\end{array}$ & $\begin{array}{l}0.008 \\
(2.26) \\
{[1.44]}\end{array}$ & $\begin{array}{l}-0.003 \\
(-1.02) \\
{[-0.76]}\end{array}$ & $\begin{array}{l}-0.003 \\
(-1.02) \\
{[-0.77]}\end{array}$ & $\begin{array}{l}-0.002 \\
(-0.74) \\
{[-0.55]}\end{array}$ \\
\hline Junior & $\begin{array}{c}0.012 \\
(2.99) \\
{[1.50]}\end{array}$ & $\begin{array}{l}0.012 \\
(3.05) \\
{[1.57]}\end{array}$ & $\begin{array}{c}0.010 \\
(2.49) \\
{[1.32]}\end{array}$ & $\begin{array}{c}-0.014 \\
(-4.03) \\
{[-3.25]}\end{array}$ & $\begin{array}{l}-0.015 \\
(-4.13) \\
{[-3.31]}\end{array}$ & $\begin{array}{c}-0.014 \\
(-3.90) \\
{[-3.26]}\end{array}$ \\
\hline Senior & $\begin{array}{l}0.011 \\
(2.63) \\
{[1.19]}\end{array}$ & $\begin{array}{c}0.011 \\
(2.76) \\
{[1.26]}\end{array}$ & $\begin{array}{c}0.007 \\
(1.78) \\
{[0.86]}\end{array}$ & $\begin{array}{l}-0.018 \\
(-4.95) \\
{[-3.59]}\end{array}$ & $\begin{array}{l}-0.019 \\
(-5.01) \\
{[-3.59]}\end{array}$ & $\begin{array}{l}-0.019 \\
(-5.05) \\
{[-3.70]}\end{array}$ \\
\hline Graduate student & $\begin{array}{c}-0.070 \\
(-10.57) \\
{[-5.87]}\end{array}$ & $\begin{array}{r}-0.072 \\
(-10.94) \\
{[-5.97]}\end{array}$ & $\begin{array}{r}-0.067 \\
(-10.21) \\
{[-5.22]}\end{array}$ & $\begin{array}{l}-0.041 \\
(-6.97) \\
{[-5.35]}\end{array}$ & $\begin{array}{l}-0.042 \\
(-7.11) \\
{[-5.40]}\end{array}$ & $\begin{array}{l}-0.040 \\
(-6.77) \\
{[-4.81]}\end{array}$ \\
\hline Non-matriculated & $\begin{array}{c}0.001 \\
(0.14) \\
{[0.12]}\end{array}$ & $\begin{array}{l}-0.001 \\
(-0.15) \\
{[-0.13]}\end{array}$ & $\begin{array}{l}-0.001 \\
(-0.15) \\
{[-0.12]}\end{array}$ & $\begin{array}{l}-0.005 \\
(-0.61) \\
{[-0.55]}\end{array}$ & $\begin{array}{l}-0.006 \\
(-0.70) \\
{[-0.62]}\end{array}$ & $\begin{array}{l}-0.006 \\
(-0.78) \\
{[-0.72]}\end{array}$ \\
\hline Black & $\begin{array}{r}-0.163 \\
(-26.37) \\
{[-15.57]}\end{array}$ & $\begin{array}{c}-0.168 \\
(-26.98) \\
{[-15.43]}\end{array}$ & $\begin{array}{c}-0.164 \\
(-26.22) \\
{[-15.09]}\end{array}$ & $\begin{array}{r}-0.059 \\
(-11.15) \\
{[-7.07]}\end{array}$ & $\begin{array}{c}-0.059 \\
(-11.11) \\
{[-7.16]}\end{array}$ & $\begin{array}{r}-0.056 \\
(-10.41) \\
{[-6.64]}\end{array}$ \\
\hline
\end{tabular}


Table 3 (continued)

\begin{tabular}{|c|c|c|c|c|c|c|}
\hline Hispanic & $\begin{array}{c}-0.082 \\
(-12.81) \\
{[-7.11]}\end{array}$ & $\begin{array}{c}-0.084 \\
(-13.10) \\
{[-7.12]}\end{array}$ & $\begin{array}{c}-0.073 \\
(-11.33) \\
{[-5.46]}\end{array}$ & $\begin{array}{c}-0.029 \\
(-5.05) \\
{[-4.27]}\end{array}$ & $\begin{array}{c}-0.030 \\
(-5.18) \\
{[-4.39]}\end{array}$ & $\begin{array}{c}-0.024 \\
(-4.23) \\
{[-3.73]}\end{array}$ \\
\hline Other race & $\begin{array}{c}-0.144 \\
(-27.93) \\
{[-17.13]}\end{array}$ & $\begin{array}{c}-0.144 \\
(-27.77) \\
{[-16.88]}\end{array}$ & $\begin{array}{r}-0.134 \\
(-25.71) \\
{[-16.70]}\end{array}$ & $\begin{array}{c}-0.044 \\
(-9.36) \\
{[-8.05]}\end{array}$ & $\begin{array}{c}-0.044 \\
(-9.47) \\
{[-8.16]}\end{array}$ & $\begin{array}{c}-0.041 \\
(-8.64) \\
{[-7.77]}\end{array}$ \\
\hline Female & $\begin{array}{l}-0.022 \\
(-7.99) \\
{[-4.34]}\end{array}$ & $\begin{array}{c}-0.022 \\
(-7.83) \\
{[-4.27]}\end{array}$ & $\begin{array}{l}-0.025 \\
(-8.90) \\
{[-5.08]}\end{array}$ & $\begin{array}{c}-0.001 \\
(-0.50) \\
{[-0.31]}\end{array}$ & $\begin{array}{c}-0.001 \\
(-0.44) \\
{[-0.27]}\end{array}$ & $\begin{array}{c}-0.002 \\
(-0.98) \\
{[-0.64]}\end{array}$ \\
\hline Married & $\begin{array}{c}-0.114 \\
(-22.34) \\
{[-18.19]}\end{array}$ & $\begin{array}{c}-0.112 \\
(-22.05) \\
{[-19.05]}\end{array}$ & $\begin{array}{c}-0.108 \\
(-21.16) \\
{[-18.96]}\end{array}$ & $\begin{array}{r}-0.070 \\
(-15.66) \\
{[-18.68]}\end{array}$ & $\begin{array}{c}-0.069 \\
(-15.48) \\
{[-18.22]}\end{array}$ & $\begin{array}{r}-0.067 \\
(-14.98) \\
{[-17.30]}\end{array}$ \\
\hline Divorced & $\begin{array}{l}-0.035 \\
(-4.53) \\
{[-3.96]}\end{array}$ & $\begin{array}{l}-0.033 \\
(-4.31) \\
{[-3.66]}\end{array}$ & $\begin{array}{l}-0.030 \\
(-3.94) \\
{[-3.27]}\end{array}$ & $\begin{array}{c}0.007 \\
(1.06) \\
{[0.83]}\end{array}$ & $\begin{array}{c}0.008 \\
(1.16) \\
{[0.91]}\end{array}$ & $\begin{array}{c}0.009 \\
(1.29) \\
{[0.99]}\end{array}$ \\
\hline Works full-time & $\begin{array}{c}-0.008 \\
(-1.75) \\
{[-1.43]}\end{array}$ & $\begin{array}{c}-0.009 \\
(-1.87) \\
{[-1.52]}\end{array}$ & $\begin{array}{l}-0.010 \\
(-1.98) \\
{[-1.62]}\end{array}$ & $\begin{array}{c}-0.001 \\
(-0.21) \\
{[-0.18]}\end{array}$ & $\begin{array}{c}-0.001 \\
(-0.15) \\
{[-0.12]}\end{array}$ & $\begin{array}{c}-0.001 \\
(-0.33) \\
{[-0.27]}\end{array}$ \\
\hline Works part-time & $\begin{array}{c}-0.009 \\
(-3.02) \\
{[-1.47]}\end{array}$ & $\begin{array}{c}-0.009 \\
(-2.93) \\
{[-1.47]}\end{array}$ & $\begin{array}{l}-0.010 \\
(-3.26) \\
{[-1.75]}\end{array}$ & $\begin{array}{c}-0.005 \\
(-1.85) \\
{[-1.42]}\end{array}$ & $\begin{array}{c}-0.005 \\
(-1.79) \\
{[-1.41]}\end{array}$ & $\begin{array}{c}-0.005 \\
(-1.84) \\
{[-1.51]}\end{array}$ \\
\hline Lives in on-campus housing & $\begin{array}{c}0.001 \\
(0.21) \\
{[0.07]}\end{array}$ & $\begin{array}{c}0.001 \\
(0.22) \\
{[0.07]}\end{array}$ & $\begin{array}{l}-0.007 \\
(-1.98) \\
{[-0.68]}\end{array}$ & $\begin{array}{c}0.021 \\
(7.29) \\
{[4.34]}\end{array}$ & $\begin{array}{c}0.021 \\
(7.36) \\
{[4.36]}\end{array}$ & $\begin{array}{r}0.017 \\
(5.90) \\
{[4.00]}\end{array}$ \\
\hline Lives in a fraternity/sorority & $\begin{array}{c}0.166 \\
(16.18) \\
{[8.48]}\end{array}$ & $\begin{array}{c}0.170 \\
(16.50) \\
{[8.98]}\end{array}$ & $\begin{array}{r}0.171 \\
(16.70) \\
{[9.86]}\end{array}$ & $\begin{array}{c}0.073 \\
(7.58) \\
{[5.72]}\end{array}$ & $\begin{array}{c}0.073 \\
(7.59) \\
{[5.79]}\end{array}$ & $\begin{array}{c}0.072 \\
(7.54) \\
{[6.02]}\end{array}$ \\
\hline Father has alcohol/drug problems & $\begin{array}{r}0.052 \\
(13.96) \\
{[14.09]}\end{array}$ & $\begin{array}{r}0.051 \\
(13.91) \\
{[14.06]}\end{array}$ & $\begin{array}{c}0.052 \\
(14.17) \\
{[14.47]}\end{array}$ & $\begin{array}{r}0.042 \\
(12.77) \\
{[11.58]}\end{array}$ & $\begin{array}{r}0.041 \\
(12.73) \\
{[11.57]}\end{array}$ & $\begin{array}{r}0.042 \\
(12.85) \\
{[11.77]}\end{array}$ \\
\hline 1990 & $\begin{array}{c}-0.029 \\
(-7.89) \\
{[-1.63]}\end{array}$ & $\begin{array}{l}-0.026 \\
(-6.76) \\
{[-1.47]}\end{array}$ & $\begin{array}{c}-0.028 \\
(-7.33) \\
{[-1.80]}\end{array}$ & $\begin{array}{c}0.006 \\
(1.10) \\
{[0.95]}\end{array}$ & $\begin{array}{c}0.008 \\
(1.34) \\
{[1.04]}\end{array}$ & $\begin{array}{c}-0.001 \\
(-0.20) \\
{[-0.14]}\end{array}$ \\
\hline 1991 & $\begin{array}{c}-0.022 \\
(-6.61) \\
{[-1.66]}\end{array}$ & $\begin{array}{c}-0.004 \\
(-1.12) \\
{[-0.27]}\end{array}$ & $\begin{array}{c}-0.009 \\
(-2.26) \\
{[-0.70]}\end{array}$ & $\begin{array}{c}-0.005 \\
(-1.98) \\
{[-1.01]}\end{array}$ & $\begin{array}{l}0.000004 \\
(0.001) \\
{[0.00]}\end{array}$ & $\begin{array}{l}0.0002 \\
(0.07) \\
{[0.05]}\end{array}$ \\
\hline R-squared & 0.063 & 0.064 & 0.068 & 0.029 & 0.029 & 0.030 \\
\hline F-statistic & 338.811 & 303.887 & 272.181 & 110.989 & 98.579 & 86.554 \\
\hline
\end{tabular}

\footnotetext{
${ }^{a}$ t-statistics in parentheses, Huber t-statistics in brackets, and intercepts not shown.
} 
Table 4

Demand Equations ${ }^{\mathrm{a}}$

$$
(n=118,177)
$$

\begin{tabular}{|c|c|c|c|}
\hline & \multicolumn{3}{|c|}{ Average Number of Drinks Per Week } \\
\hline & (1) & (2) & (3) \\
\hline Real beer price & $\begin{array}{c}-1.762 \\
(-15.24) \\
{[-2.35]}\end{array}$ & $\begin{array}{r}-1.864 \\
(-15.88) \\
{[-2.44]}\end{array}$ & $\begin{array}{c}-1.408 \\
(-10.14) \\
{[-1.57]}\end{array}$ \\
\hline Real income & & $\begin{array}{c}0.0003 \\
(10.14) \\
{[2.18]}\end{array}$ & $\begin{array}{l}0.0003 \\
(8.74) \\
{[2.11]}\end{array}$ \\
\hline Number of licensed outlets per capita & & $\begin{array}{r}545.125 \\
(15.22) \\
{[2.88]}\end{array}$ & $\begin{array}{c}797.742 \\
(17.26) \\
{[3.41]}\end{array}$ \\
\hline Marijuana decriminalization & & $\begin{array}{c}0.063 \\
(1.21) \\
{[0.20]}\end{array}$ & $\begin{array}{c}0.062 \\
(1.06) \\
{[0.21]}\end{array}$ \\
\hline Mormon & & & $\begin{array}{c}0.015 \\
(3.50) \\
{[0.88]}\end{array}$ \\
\hline Southern Baptist & & & $\begin{array}{c}0.015 \\
(2.67) \\
{[0.57]}\end{array}$ \\
\hline Protestant & & & $\begin{array}{c}0.030 \\
(8.52) \\
{[1.70]}\end{array}$ \\
\hline Catholic & & & $\begin{array}{r}0.060 \\
(20.22) \\
{[3.75]}\end{array}$ \\
\hline Jewish & & & $\begin{array}{c}0.010 \\
(0.76) \\
{[0.12]}\end{array}$ \\
\hline Age & $\begin{array}{r}-0.054 \\
(-10.19) \\
{[-5.55]}\end{array}$ & $\begin{array}{c}-0.054 \\
(-10.25) \\
{[-5.61]}\end{array}$ & $\begin{array}{c}-0.053 \\
(-10.00) \\
{[-5.53]}\end{array}$ \\
\hline Sophomore & $\begin{array}{c}0.053 \\
(0.78) \\
{[0.47]}\end{array}$ & $\begin{array}{c}0.094 \\
(1.38) \\
{[0.87]}\end{array}$ & $\begin{array}{c}0.140 \\
(2.07) \\
{[1.30]}\end{array}$ \\
\hline Junior & $\begin{array}{c}0.443 \\
(6.02) \\
{[2.71]}\end{array}$ & $\begin{array}{c}0.478 \\
(6.50) \\
{[3.01]}\end{array}$ & $\begin{array}{c}0.444 \\
(6.04) \\
{[2.95]}\end{array}$ \\
\hline Senior & $\begin{array}{c}0.594 \\
(7.83) \\
{[2.82]}\end{array}$ & $\begin{array}{c}0.629 \\
(8.27) \\
{[3.05]}\end{array}$ & $\begin{array}{c}0.543 \\
(7.16) \\
{[2.81]}\end{array}$ \\
\hline Graduate student & $\begin{array}{c}-0.438 \\
(-3.63) \\
{[-2.04]}\end{array}$ & $\begin{array}{l}-0.471 \\
(-3.91) \\
{[-2.16]}\end{array}$ & $\begin{array}{l}-0.376 \\
(-3.12) \\
{[-1.60]}\end{array}$ \\
\hline Non-matriculated & $\begin{array}{c}0.664 \\
(3.91) \\
{[2.30]}\end{array}$ & $\begin{array}{c}0.613 \\
(3.61) \\
{[2.29]}\end{array}$ & $\begin{array}{c}0.610 \\
(3.60) \\
{[2.35]}\end{array}$ \\
\hline
\end{tabular}


Table 4 (continued)

\begin{tabular}{|c|c|c|c|}
\hline Black & $\begin{array}{r}-3.250 \\
(-28.68) \\
{[-16.60]}\end{array}$ & $\begin{array}{r}-3.449 \\
(-30.24) \\
{[-14.89]}\end{array}$ & $\begin{array}{r}-3.367 \\
(-29.49) \\
{[-15.29]}\end{array}$ \\
\hline Hispanic & $\begin{array}{r}-1.786 \\
(-15.21) \\
{[-10.00]}\end{array}$ & $\begin{array}{r}-1.814 \\
(-15.43) \\
{[-10.68]}\end{array}$ & $\begin{array}{r}-1.653 \\
(-13.98) \\
{[-9.49]}\end{array}$ \\
\hline Other race & $\begin{array}{r}-2.444 \\
(-26.10) \\
{[-13.32]}\end{array}$ & $\begin{array}{r}-2.427 \\
(-25.85) \\
{[-13.55]}\end{array}$ & $\begin{array}{r}-2.269 \\
(-24.07) \\
{[-13.34]}\end{array}$ \\
\hline Female & $\begin{array}{c}-3.923 \\
(-76.32) \\
{[-23.72]}\end{array}$ & $\begin{array}{r}-3.915 \\
(-76.23) \\
{[-24.00]}\end{array}$ & $\begin{array}{r}-3.970 \\
(-77.37) \\
{[-25.30]}\end{array}$ \\
\hline Married & $\begin{array}{c}-1.903 \\
(-20.45) \\
{[-11.98]}\end{array}$ & $\begin{array}{r}-1.875 \\
(-20.15) \\
{[-12.82]}\end{array}$ & $\begin{array}{r}-1.789 \\
(-19.23) \\
{[-12.25]}\end{array}$ \\
\hline Divorced & $\begin{array}{c}0.166 \\
(1.17) \\
{[0.62]}\end{array}$ & $\begin{array}{c}0.208 \\
(1.47) \\
{[0.77]}\end{array}$ & $\begin{array}{c}0.264 \\
(1.86) \\
{[0.97]}\end{array}$ \\
\hline Part-time student & $\begin{array}{c}-0.114 \\
(-1.33) \\
{[-0.84]}\end{array}$ & $\begin{array}{c}-0.109 \\
(-1.27) \\
{[-0.84]}\end{array}$ & $\begin{array}{l}-0.092 \\
(-1.08) \\
{[-0.71]}\end{array}$ \\
\hline Works full-time & $\begin{array}{c}-0.827 \\
(-9.35) \\
{[-4.99]}\end{array}$ & $\begin{array}{l}-0.850 \\
(-9.62) \\
{[-5.25]}\end{array}$ & $\begin{array}{l}-0.868 \\
(-9.85) \\
{[-5.44]}\end{array}$ \\
\hline Works part-time & $\begin{array}{c}-1.232 \\
(-22.78) \\
{[-8.42]}\end{array}$ & $\begin{array}{c}-1.213 \\
(-22.44) \\
{[-8.54]}\end{array}$ & $\begin{array}{c}-1.225 \\
(-22.71) \\
{[-8.97]}\end{array}$ \\
\hline Lives in on-campus housing & $\begin{array}{r}1.175 \\
(18.93) \\
{[3.99]}\end{array}$ & $\begin{array}{c}1.159 \\
(18.66) \\
{[3.96]}\end{array}$ & $\begin{array}{c}1.010 \\
(16.19) \\
{[3.73]}\end{array}$ \\
\hline Lives in a fraternity/sorority & $\begin{array}{r}6.175 \\
(32.82) \\
{[6.07]}\end{array}$ & $\begin{array}{c}6.204 \\
(32.96) \\
{[6.21]}\end{array}$ & $\begin{array}{c}6.274 \\
(33.39) \\
{[6.54]}\end{array}$ \\
\hline On campus residence unknown & $\begin{array}{c}-0.202 \\
(-2.67) \\
{[-1.01]}\end{array}$ & $\begin{array}{c}-0.173 \\
(-2.29) \\
{[-0.87]}\end{array}$ & $\begin{array}{c}-0.102 \\
(-1.35) \\
{[-0.52]}\end{array}$ \\
\hline Mother has alcohol/drug problems & $\begin{array}{l}0.922 \\
(8.42) \\
{[5.33]}\end{array}$ & $\begin{array}{c}0.931 \\
(8.51) \\
{[5.40]}\end{array}$ & $\begin{array}{c}0.968 \\
(8.86) \\
{[5.61]}\end{array}$ \\
\hline Father has alcohol/drug problems & $\begin{array}{c}0.573 \\
(8.41) \\
{[6.82]}\end{array}$ & $\begin{array}{c}0.573 \\
(8.41) \\
{[6.80]}\end{array}$ & $\begin{array}{c}0.589 \\
(8.68) \\
{[6.92]}\end{array}$ \\
\hline 1990 & $\begin{array}{c}-0.311 \\
(-4.66) \\
{[-0.79]}\end{array}$ & $\begin{array}{c}-0.223 \\
(-3.25) \\
{[-0.58]}\end{array}$ & $\begin{array}{c}-0.271 \\
(-3.92) \\
{[-0.77]}\end{array}$ \\
\hline 1991 & $\begin{array}{c}-0.050 \\
(-0.82) \\
{[-0.16]}\end{array}$ & $\begin{array}{c}0.312 \\
(4.36) \\
{[0.97]}\end{array}$ & $\begin{array}{c}0.268 \\
(3.62) \\
{[0.98]}\end{array}$ \\
\hline R-squared & 0.100 & 0.102 & 0.107 \\
\hline F-statistic & 568.390 & 513.464 & 454.585 \\
\hline
\end{tabular}

${ }^{\mathrm{a}} \mathrm{t}$-statistics in parentheses, Huber t-statistics in brackets, and intercepts not shown. 
Table 5

Price, Income, and Outlet Elasticities

\begin{tabular}{lccc}
\hline & $\begin{array}{c}\text { Beer price and } \\
\text { individual } \\
\text { characteristics }\end{array}$ & $\begin{array}{c}\text { Beer price, marijuana } \\
\text { decriminalization, } \\
\text { income, outlets and } \\
\text { individual } \\
\text { characteristics }\end{array}$ & $\begin{array}{c}\text { Beer price, marijuana } \\
\text { decriminalization, } \\
\text { income, outlets, religion } \\
\text { and individual } \\
\text { characteristics }\end{array}$ \\
\hline TROUBLE & -0.500 & -0.457 & -0.477 \\
Price & & 0.733 & 0.444 \\
Income & & 0.002 & 0.124 \\
Number of outlets & -0.590 & & -0.354 \\
DAMAGE & & -0.624 & -0.029 \\
Price & & 0.108 & 0.276 \\
Income & & 0.180 & -0.281 \\
Number of outlets & & 0.330 \\
& -0.360 & -0.362 & 0.159 \\
FIGHT & & 0.474 & \\
Price & & 0.115 & -0.076 \\
Income & & & 0.414 \\
Number of outlets & & -0.485 & 0.116 \\
SEXUAL ADVANTAGE & -0.532 & 0.289 & -0.744 \\
Price & & 0.028 & 0.619 \\
Income & & & 0.397 \\
Number of outlets & & -0.985 & \\
NUMBER OF DRINKS & 0.638 & \\
Price & & 0.271 & \\
Income & & & \\
Number of outlets & & & \\
\hline
\end{tabular}


Table 6

Two-Stage Least Squares

Structural Violence Estimates ${ }^{\mathrm{a}}$

\begin{tabular}{|c|c|c|c|c|c|c|}
\hline & \multicolumn{3}{|c|}{$\begin{array}{c}\text { Trouble } \\
(n=113,553)\end{array}$} & \multicolumn{3}{|c|}{$\begin{array}{c}\text { Damage } \\
(\mathrm{n}=113,275)\end{array}$} \\
\hline & (1) & (2) & (3) & (1) & (2) & (3) \\
\hline Number of drinks & $\begin{array}{c}0.014 \\
(5.90) \\
{[1.97]}\end{array}$ & $\begin{array}{c}0.007 \\
(3.83) \\
{[0.95]}\end{array}$ & $\begin{array}{c}0.010 \\
(5.78) \\
{[1.83]}\end{array}$ & $\begin{array}{c}0.010 \\
(5.17) \\
{[3.65]}\end{array}$ & $\begin{array}{c}0.010 \\
(7.38) \\
{[4.62]}\end{array}$ & $\begin{array}{c}0.010 \\
(6.88) \\
{[4.47]}\end{array}$ \\
\hline Real income & & $\begin{array}{l}0.00001 \\
(8.32) \\
{[3.12]}\end{array}$ & $\begin{array}{l}0.000003 \\
(2.73) \\
{[1.13]}\end{array}$ & & $\begin{array}{l}-0.000002 \\
(-2.77) \\
{[-1.93]}\end{array}$ & $\begin{array}{l}-0.000003 \\
(-3.71) \\
{[-2.67]}\end{array}$ \\
\hline Marijuana decriminalization & & $\begin{array}{c}0.001 \\
(0.57) \\
{[0.17]}\end{array}$ & $\begin{array}{l}-0.001 \\
(-0.54) \\
{[-0.20]}\end{array}$ & & $\begin{array}{c}0.001 \\
(0.84) \\
{[0.56]}\end{array}$ & $\begin{array}{l}-0.001 \\
(-0.71) \\
{[-0.47]}\end{array}$ \\
\hline Mormon & & & $\begin{array}{l}-0.00002 \\
(-0.17) \\
{[-0.07]}\end{array}$ & & & $\begin{array}{l}-0.0002 \\
(-1.70) \\
{[-1.50]}\end{array}$ \\
\hline Southern Baptist & & & $\begin{array}{l}-0.001 \\
(-5.73) \\
{[-1.89]}\end{array}$ & & & $\begin{array}{l}-0.0002 \\
(-1.11) \\
{[-0.81]}\end{array}$ \\
\hline Protestant & & & $\begin{array}{c}0.001 \\
(5.69) \\
{[1.84]}\end{array}$ & & & $\begin{array}{l}0.0003 \\
(3.33) \\
{[2.18]}\end{array}$ \\
\hline Catholic & & & $\begin{array}{l}0.0004 \\
(3.18) \\
{[0.98]}\end{array}$ & & & $\begin{array}{l}0.0001 \\
(1.28) \\
{[0.81]}\end{array}$ \\
\hline Jewish & & & $\begin{array}{l}-0.003 \\
(-6.16) \\
{[-1.94]}\end{array}$ & & & $\begin{array}{l}0.0004 \\
(1.01) \\
{[0.71]}\end{array}$ \\
\hline Age & $\begin{array}{l}-0.002 \\
(-8.46) \\
{[-4.64]}\end{array}$ & $\begin{array}{r}-0.003 \\
(-11.20) \\
{[-5.55]}\end{array}$ & $\begin{array}{r}-0.002 \\
(-10.47) \\
{[-6.42]}\end{array}$ & $\begin{array}{c}-0.002 \\
(-8.07) \\
{[-7.60]}\end{array}$ & $\begin{array}{l}-0.002 \\
(-8.62) \\
{[-8.66]}\end{array}$ & $\begin{array}{l}-0.002 \\
(-8.67) \\
{[-9.05]}\end{array}$ \\
\hline Sophomore & $\begin{array}{c}0.001 \\
(0.45) \\
{[0.30]}\end{array}$ & $\begin{array}{c}0.001 \\
(0.57) \\
{[0.36]}\end{array}$ & $\begin{array}{c}0.001 \\
(0.50) \\
{[0.34]}\end{array}$ & $\begin{array}{l}-0.002 \\
(-0.96) \\
{[-0.76]}\end{array}$ & $\begin{array}{l}-0.002 \\
(-0.95) \\
{[-0.75]}\end{array}$ & $\begin{array}{c}-0.002 \\
(-0.88) \\
{[-0.69]}\end{array}$ \\
\hline Junior & $\begin{array}{l}-0.016 \\
(-5.30) \\
{[-3.08]}\end{array}$ & $\begin{array}{l}-0.013 \\
(-4.52) \\
{[-2.56]}\end{array}$ & $\begin{array}{l}-0.016 \\
(-5.54) \\
{[-3.66]}\end{array}$ & $\begin{array}{l}-0.007 \\
(-2.74) \\
{[-2.25]}\end{array}$ & $\begin{array}{l}-0.007 \\
(-2.84) \\
{[-2.28]}\end{array}$ & $\begin{array}{l}-0.007 \\
(-2.94) \\
{[-2.43]}\end{array}$ \\
\hline Senior & $\begin{array}{r}-0.040 \\
(-12.35) \\
{[-6.48]}\end{array}$ & $\begin{array}{r}-0.035 \\
(-11.58) \\
{[-5.99]}\end{array}$ & $\begin{array}{r}-0.039 \\
(-12.91) \\
{[-7.70]}\end{array}$ & $\begin{array}{l}-0.017 \\
(-6.51) \\
{[-4.95]}\end{array}$ & $\begin{array}{l}-0.017 \\
(-6.97) \\
{[-5.25]}\end{array}$ & $\begin{array}{l}-0.017 \\
(-7.19) \\
{[-5.47]}\end{array}$ \\
\hline Graduate student & $\begin{array}{r}-0.046 \\
(-10.08) \\
{[-8.05]}\end{array}$ & $\begin{array}{r}-0.051 \\
(-11.07) \\
{[-7.56]}\end{array}$ & $\begin{array}{r}-0.047 \\
(-10.28) \\
{[-7.69]}\end{array}$ & $\begin{array}{l}-0.022 \\
(-5.98) \\
{[-6.31]}\end{array}$ & $\begin{array}{c}-0.022 \\
(-5.84) \\
{[-6.11]}\end{array}$ & $\begin{array}{c}-0.021 \\
(-5.74) \\
{[-5.77]}\end{array}$ \\
\hline Non-matriculated & $\begin{array}{l}-0.020 \\
(-2.96) \\
{[-2.81]}\end{array}$ & $\begin{array}{l}-0.016 \\
(-2.40) \\
{[-2.37]}\end{array}$ & $\begin{array}{l}-0.016 \\
(-2.48) \\
{[-2.67]}\end{array}$ & $\begin{array}{l}-0.004 \\
(-0.75) \\
{[-0.82]}\end{array}$ & $\begin{array}{c}-0.004 \\
(-0.70) \\
{[-0.79]}\end{array}$ & $\begin{array}{c}-0.004 \\
(-0.68) \\
{[-0.79]}\end{array}$ \\
\hline Black & $\begin{array}{l}-0.029 \\
(-3.29) \\
{[-1.25]}\end{array}$ & $\begin{array}{l}-0.053 \\
(-7.52) \\
{[-2.34]}\end{array}$ & $\begin{array}{l}-0.036 \\
(-5.07) \\
{[-1.96]}\end{array}$ & $\begin{array}{l}-0.015 \\
(-2.06) \\
{[-1.59]}\end{array}$ & $\begin{array}{l}-0.014 \\
(-2.53) \\
{[-1.85]}\end{array}$ & $\begin{array}{l}-0.014 \\
(-2.47) \\
{[-1.83]}\end{array}$ \\
\hline
\end{tabular}


Table 6 (continued)

\begin{tabular}{|c|c|c|c|c|c|c|}
\hline Hispanic & $\begin{array}{l}-0.015 \\
(-2.46) \\
{[-1.12]}\end{array}$ & $\begin{array}{c}-0.029 \\
(-5.42) \\
{[-2.13]}\end{array}$ & $\begin{array}{l}-0.016 \\
(-2.95) \\
{[-1.48]}\end{array}$ & $\begin{array}{c}-0.008 \\
(-1.54) \\
{[-1.26]}\end{array}$ & $\begin{array}{c}-0.007 \\
(-1.65) \\
{[-1.38]}\end{array}$ & $\begin{array}{c}-0.006 \\
(-1.32) \\
{[-1.09]}\end{array}$ \\
\hline Other race & $\begin{array}{l}-0.020 \\
(-3.00) \\
{[-1.18]}\end{array}$ & $\begin{array}{c}-0.038 \\
(-6.98) \\
{[-2.25]}\end{array}$ & $\begin{array}{l}-0.025 \\
(-4.55) \\
{[-1.93]}\end{array}$ & $\begin{array}{c}-0.014 \\
(-2.58) \\
{[-2.04]}\end{array}$ & $\begin{array}{l}-0.014 \\
(-3.14) \\
{[-2.46]}\end{array}$ & $\begin{array}{c}-0.013 \\
(-2.90) \\
{[-2.23]}\end{array}$ \\
\hline Female & $\begin{array}{c}-0.044 \\
(-4.57) \\
{[-1.57]}\end{array}$ & $\begin{array}{r}-0.074 \\
(-10.38) \\
{[-2.71]}\end{array}$ & $\begin{array}{c}-0.059 \\
(-7.96) \\
{[-2.62]}\end{array}$ & $\begin{array}{c}-0.070 \\
(-9.06) \\
{[-6.23]}\end{array}$ & $\begin{array}{c}-0.070 \\
(-12.28) \\
{[-7.18]}\end{array}$ & $\begin{array}{r}-0.071 \\
(-11.83) \\
{[-7.38]}\end{array}$ \\
\hline Married & $\begin{array}{c}-0.021 \\
(-3.57) \\
{[-1.46]}\end{array}$ & $\begin{array}{c}-0.035 \\
(-7.19) \\
{[-2.53]}\end{array}$ & $\begin{array}{c}-0.028 \\
(-5.87) \\
{[-2.64]}\end{array}$ & $\begin{array}{c}-0.013 \\
(-2.79) \\
{[-2.36]}\end{array}$ & $\begin{array}{l}-0.013 \\
(-3.30) \\
{[-2.81]}\end{array}$ & $\begin{array}{c}-0.013 \\
(-3.29) \\
{[-2.84]}\end{array}$ \\
\hline Divorced & $\begin{array}{c}-0.014 \\
(-2.62) \\
{[-2.98]}\end{array}$ & $\begin{array}{c}-0.013 \\
(-2.39) \\
{[-2.82]}\end{array}$ & $\begin{array}{c}-0.013 \\
(-2.53) \\
{[-2.92]}\end{array}$ & $\begin{array}{c}0.001 \\
(0.34) \\
{[0.47]}\end{array}$ & $\begin{array}{c}0.001 \\
(0.31) \\
{[0.43]}\end{array}$ & $\begin{array}{c}0.002 \\
(0.42) \\
{[0.56]}\end{array}$ \\
\hline Works full-time & $\begin{array}{c}-0.024 \\
(-5.95) \\
{[-3.30]}\end{array}$ & $\begin{array}{c}-0.031 \\
(-8.27) \\
{[-4.15]}\end{array}$ & $\begin{array}{l}-0.027 \\
(-7.22) \\
{[-4.13]}\end{array}$ & $\begin{array}{l}-0.010 \\
(-3.23) \\
{[-3.04]}\end{array}$ & $\begin{array}{c}-0.010 \\
(-3.41) \\
{[-3.28]}\end{array}$ & $\begin{array}{l}-0.010 \\
(-3.45) \\
{[-3.23]}\end{array}$ \\
\hline Works part-time & $\begin{array}{c}-0.012 \\
(-3.44) \\
{[-1.35]}\end{array}$ & $\begin{array}{l}-0.022 \\
(-7.44) \\
{[-2.51]}\end{array}$ & $\begin{array}{l}-0.018 \\
(-6.02) \\
{[-2.46]}\end{array}$ & $\begin{array}{l}0.0002 \\
(0.07) \\
{[0.05]}\end{array}$ & $\begin{array}{c}0.001 \\
(0.26) \\
{[0.19]}\end{array}$ & $\begin{array}{l}0.0001 \\
(0.05) \\
{[0.04]}\end{array}$ \\
\hline Lives in on-campus housing & $\begin{array}{c}0.030 \\
(7.84) \\
{[3.02]}\end{array}$ & $\begin{array}{r}0.039 \\
(12.41) \\
{[4.07]}\end{array}$ & $\begin{array}{c}0.034 \\
(11.32) \\
{[4.30]}\end{array}$ & $\begin{array}{c}-0.008 \\
(-2.61) \\
{[-1.86]}\end{array}$ & $\begin{array}{c}-0.008 \\
(-3.29) \\
{[-2.24]}\end{array}$ & $\begin{array}{c}-0.009 \\
(-3.74) \\
{[-2.54]}\end{array}$ \\
\hline Lives in a fraternity/sorority & $\begin{array}{c}-0.005 \\
(-0.33) \\
{[-0.12]}\end{array}$ & $\begin{array}{l}0.043 \\
(3.41) \\
{[0.99]}\end{array}$ & $\begin{array}{c}0.020 \\
(1.58) \\
{[0.56]}\end{array}$ & $\begin{array}{l}0.029 \\
(2.22) \\
{[1.54]}\end{array}$ & $\begin{array}{l}0.027 \\
(2.63) \\
{[1.55]}\end{array}$ & $\begin{array}{c}0.028 \\
(2.69) \\
{[1.47]}\end{array}$ \\
\hline Father has alcohol/drug problems & $\begin{array}{c}0.018 \\
(6.39) \\
{[3.74]}\end{array}$ & $\begin{array}{l}0.022 \\
(8.17) \\
{[4.83]}\end{array}$ & $\begin{array}{c}0.020 \\
(7.52) \\
{[5.16]}\end{array}$ & $\begin{array}{c}0.014 \\
(6.25) \\
{[5.65]}\end{array}$ & $\begin{array}{c}0.014 \\
(6.59) \\
{[6.36]}\end{array}$ & $\begin{array}{l}0.015 \\
(6.65) \\
{[6.48]}\end{array}$ \\
\hline 1990 & $\begin{array}{c}-0.012 \\
(-4.18) \\
{[-1.58]}\end{array}$ & $\begin{array}{c}-0.015 \\
(-5.46) \\
{[-1.83]}\end{array}$ & $\begin{array}{c}-0.013 \\
(-4.68) \\
{[-1.85]}\end{array}$ & $\begin{array}{c}0.009 \\
(4.05) \\
{[2.75]}\end{array}$ & $\begin{array}{c}0.010 \\
(4.36) \\
{[2.97]}\end{array}$ & $\begin{array}{c}0.009 \\
(3.84) \\
{[2.66]}\end{array}$ \\
\hline 1991 & $\begin{array}{c}-0.005 \\
(-1.90) \\
{[-0.76]}\end{array}$ & $\begin{array}{l}0.003 \\
(0.99) \\
{[0.36]}\end{array}$ & $\begin{array}{l}-0.0002 \\
(-0.07) \\
{[-0.03]}\end{array}$ & $\begin{array}{l}0.005 \\
(2.38) \\
{[1.68]}\end{array}$ & $\begin{array}{l}0.002 \\
(1.15) \\
{[0.76]}\end{array}$ & $\begin{array}{c}0.002 \\
(0.70) \\
{[0.46]}\end{array}$ \\
\hline R-squared & 0.065 & 0.065 & 0.068 & 0.064 & 0.065 & 0.066 \\
\hline F-statistic & 344.887 & 313.102 & 276.554 & 338.922 & 312.916 & 267.296 \\
\hline Wu F-ratio & 0.513 & 11.676 & 1.263 & 0.122 & 0.415 & 0.211 \\
\hline
\end{tabular}

${ }^{a}$ Asymptotic t-statistics in parentheses, Huber t-statistics in brackets, and intercepts not shown. For $\mathrm{Wu} F$ test, critical values of $\mathrm{F}(1, \infty)$ are 3.84 at 5 percent and 6.64 at 1 percent. 
Table 7

Two-Stage Least Squares

Structural Violence Estimates ${ }^{\mathrm{a}}$

\begin{tabular}{|c|c|c|c|c|c|c|}
\hline & \multicolumn{3}{|c|}{$\begin{array}{c}\text { Fight } \\
(\mathrm{n}=112,888)\end{array}$} & \multicolumn{3}{|c|}{$\begin{array}{c}\text { Sexual Advantage } \\
(\mathrm{n}=85,856)\end{array}$} \\
\hline & (1) & (2) & (3) & (1) & (2) & (3) \\
\hline Number of drinks & $\begin{array}{c}0.026 \\
(7.49) \\
{[2.94]}\end{array}$ & $\begin{array}{c}0.026 \\
(10.59) \\
{[3.41]}\end{array}$ & $\begin{array}{r}0.025 \\
(10.00) \\
{[3.88]}\end{array}$ & $\begin{array}{c}0.014 \\
(5.67) \\
{[2.91]}\end{array}$ & $\begin{array}{c}0.009 \\
(4.69) \\
{[2.93]}\end{array}$ & $\begin{array}{r}0.007 \\
(3.23) \\
{[2.15]}\end{array}$ \\
\hline Real income & & $\begin{array}{l}0.00001 \\
(4.36) \\
{[1.54]}\end{array}$ & $\begin{array}{l}0.000002 \\
(1.35) \\
{[0.55]}\end{array}$ & & $\begin{array}{l}0.000003 \\
(2.63) \\
{[1.49]}\end{array}$ & $\begin{array}{l}0.000003 \\
(2.25) \\
{[1.43]}\end{array}$ \\
\hline Marijuana decriminalization & & $\begin{array}{c}0.002 \\
(0.73) \\
{[0.26]}\end{array}$ & $\begin{array}{c}-0.004 \\
(-1.45) \\
{[-0.58]}\end{array}$ & & $\begin{array}{c}0.004 \\
(1.73) \\
{[0.96]}\end{array}$ & $\begin{array}{l}-0.005 \\
(-1.67) \\
{[-1.01]}\end{array}$ \\
\hline Mormon & & & $\begin{array}{l}-0.001 \\
(-3.64) \\
{[-1.67]}\end{array}$ & & & $\begin{array}{l}-0.0003 \\
(-1.49) \\
{[-1.16]}\end{array}$ \\
\hline Southern Baptist & & & $\begin{array}{l}-0.0003 \\
(-1.02) \\
{[-0.36]}\end{array}$ & & & $\begin{array}{l}-0.001 \\
(-2.75) \\
{[-1.92]}\end{array}$ \\
\hline Protestant & & & $\begin{array}{l}0.001 \\
(7.96) \\
{[2.90]}\end{array}$ & & & $\begin{array}{l}0.0005 \\
(3.00) \\
{[1.95]}\end{array}$ \\
\hline Catholic & & & $\begin{array}{l}0.001 \\
(3.36) \\
{[1.09]}\end{array}$ & & & $\begin{array}{l}0.00005 \\
(0.24) \\
{[0.17]}\end{array}$ \\
\hline Jewish & & & $\begin{array}{l}0.00002 \\
(0.03) \\
{[0.01]}\end{array}$ & & & $\begin{array}{c}0.003 \\
(4.39) \\
{[2.48]}\end{array}$ \\
\hline Age & $\begin{array}{r}-0.007 \\
(-20.93) \\
{[-11.71]}\end{array}$ & $\begin{array}{r}-0.007 \\
(-22.93) \\
{[-12.09]}\end{array}$ & $\begin{array}{r}-0.007 \\
(-22.99) \\
{[-14.59]}\end{array}$ & $\begin{array}{l}-0.003 \\
(-9.42) \\
{[-7.47]}\end{array}$ & $\begin{array}{r}-0.003 \\
(-10.98) \\
{[-10.29]}\end{array}$ & $\begin{array}{r}-0.003 \\
(-11.12) \\
{[-9.68]}\end{array}$ \\
\hline Sophomore & $\begin{array}{c}0.004 \\
(1.15) \\
{[0.82]}\end{array}$ & $\begin{array}{c}0.004 \\
(1.04) \\
{[0.73]}\end{array}$ & $\begin{array}{l}0.005 \\
(1.28) \\
{[0.94]}\end{array}$ & $\begin{array}{c}-0.003 \\
(-0.90) \\
{[-0.71]}\end{array}$ & $\begin{array}{l}-0.003 \\
(-0.93) \\
{[-0.72]}\end{array}$ & $\begin{array}{l}-0.003 \\
(-1.02) \\
{[-0.81]}\end{array}$ \\
\hline Junior & $\begin{array}{c}0.001 \\
(0.24) \\
{[0.14]}\end{array}$ & $\begin{array}{l}0.0001 \\
(0.03) \\
{[0.02]}\end{array}$ & $\begin{array}{l}-0.001 \\
(-0.24) \\
{[-0.15]}\end{array}$ & $\begin{array}{l}-0.018 \\
(-5.02) \\
{[-4.92]}\end{array}$ & $\begin{array}{l}-0.017 \\
(-4.84) \\
{[-4.26]}\end{array}$ & $\begin{array}{l}-0.017 \\
(-4.68) \\
{[-4.28]}\end{array}$ \\
\hline Senior & $\begin{array}{l}-0.004 \\
(-0.78) \\
{[-0.42]}\end{array}$ & $\begin{array}{l}-0.004 \\
(-0.97) \\
{[-0.51]}\end{array}$ & $\begin{array}{l}-0.006 \\
(-1.35) \\
{[-0.88]}\end{array}$ & $\begin{array}{l}-0.024 \\
(-6.15) \\
{[-5.37]}\end{array}$ & $\begin{array}{l}-0.022 \\
(-5.88) \\
{[-4.70]}\end{array}$ & $\begin{array}{l}-0.022 \\
(-5.81) \\
{[-4.57]}\end{array}$ \\
\hline Graduate student & $\begin{array}{c}-0.059 \\
(-9.04) \\
{[-6.30]}\end{array}$ & $\begin{array}{l}-0.060 \\
(-9.33) \\
{[-6.66]}\end{array}$ & $\begin{array}{c}-0.058 \\
(-8.97) \\
{[-6.15]}\end{array}$ & $\begin{array}{c}-0.034 \\
(-5.85) \\
{[-4.71]}\end{array}$ & $\begin{array}{l}-0.038 \\
(-6.46) \\
{[-5.54]}\end{array}$ & $\begin{array}{l}-0.038 \\
(-6.56) \\
{[-5.21]}\end{array}$ \\
\hline Non-matriculated & $\begin{array}{l}-0.015 \\
(-1.57) \\
{[-1.12]}\end{array}$ & $\begin{array}{l}-0.016 \\
(-1.75) \\
{[-1.29]}\end{array}$ & $\begin{array}{l}-0.016 \\
(-1.72) \\
{[-1.32]}\end{array}$ & $\begin{array}{c}-0.014 \\
(-1.65) \\
{[-1.50]}\end{array}$ & $\begin{array}{l}-0.011 \\
(-1.36) \\
{[-1.23]}\end{array}$ & $\begin{array}{c}-0.011 \\
(-1.30) \\
{[-1.24]}\end{array}$ \\
\hline Black & $\begin{array}{l}-0.081 \\
(-6.34) \\
{[-2.68]}\end{array}$ & $\begin{array}{l}-0.079 \\
(-7.97) \\
{[-2.97]}\end{array}$ & $\begin{array}{l}-0.079 \\
(-7.77) \\
{[-3.59]}\end{array}$ & $\begin{array}{l}-0.013 \\
(-1.31) \\
{[-0.78]}\end{array}$ & $\begin{array}{l}-0.028 \\
(-3.33) \\
{[-2.07]}\end{array}$ & $\begin{array}{l}-0.032 \\
(-3.61) \\
{[-2.24]}\end{array}$ \\
\hline
\end{tabular}


Table 7 (continued)

\begin{tabular}{|c|c|c|c|c|c|c|}
\hline Hispanic & $\begin{array}{l}-0.033 \\
(-3.86) \\
{[-1.72]}\end{array}$ & $\begin{array}{c}-0.034 \\
(-4.49) \\
{[-1.89]}\end{array}$ & $\begin{array}{c}-0.027 \\
(-3.55) \\
{[-1.81]}\end{array}$ & $\begin{array}{c}-0.003 \\
(-0.45) \\
{[-0.30]}\end{array}$ & $\begin{array}{c}-0.012 \\
(-1.84) \\
{[-1.63]}\end{array}$ & $\begin{array}{l}-0.013 \\
(-1.94) \\
{[-1.75]}\end{array}$ \\
\hline Other race & $\begin{array}{c}-0.081 \\
(-8.49) \\
{[-3.61]}\end{array}$ & $\begin{array}{r}-0.081 \\
(-10.55) \\
{[-3.96]}\end{array}$ & $\begin{array}{c}-0.076 \\
(-9.74) \\
{[-4.46]}\end{array}$ & $\begin{array}{c}-0.009 \\
(-1.24) \\
{[-0.75]}\end{array}$ & $\begin{array}{c}-0.021 \\
(-3.18) \\
{[-2.42]}\end{array}$ & $\begin{array}{l}-0.024 \\
(-3.52) \\
{[-2.89]}\end{array}$ \\
\hline Female & $\begin{array}{c}0.078 \\
(5.70) \\
{[2.23]}\end{array}$ & $\begin{array}{c}0.079 \\
(7.95) \\
{[2.64]}\end{array}$ & $\begin{array}{c}0.076 \\
(7.25) \\
{[2.85]}\end{array}$ & $\begin{array}{c}0.054 \\
(5.34) \\
{[2.81]}\end{array}$ & $\begin{array}{c}0.036 \\
(4.29) \\
{[2.89]}\end{array}$ & $\begin{array}{c}0.026 \\
(2.81) \\
{[1.98]}\end{array}$ \\
\hline Married & $\begin{array}{c}-0.065 \\
(-7.76) \\
{[-3.66]}\end{array}$ & $\begin{array}{c}-0.064 \\
(-9.29) \\
{[-4.12]}\end{array}$ & $\begin{array}{c}-0.062 \\
(-9.29) \\
{[-4.86]}\end{array}$ & $\begin{array}{c}-0.042 \\
(-6.19) \\
{[-4.06]}\end{array}$ & $\begin{array}{c}-0.051 \\
(-8.48) \\
{[-6.90]}\end{array}$ & $\begin{array}{l}-0.053 \\
(-8.82) \\
{[-7.72]}\end{array}$ \\
\hline Divorced & $\begin{array}{c}-0.037 \\
(-4.89) \\
{[-3.99]}\end{array}$ & $\begin{array}{c}-0.036 \\
(-4.81) \\
{[-3.91]}\end{array}$ & $\begin{array}{c}-0.035 \\
(-4.56) \\
{[-3.62]}\end{array}$ & $\begin{array}{c}0.006 \\
(0.86) \\
{[0.75]}\end{array}$ & $\begin{array}{c}0.007 \\
(1.01) \\
{[0.87]}\end{array}$ & $\begin{array}{l}0.007 \\
(1.10) \\
{[0.91]}\end{array}$ \\
\hline Works full-time & $\begin{array}{c}0.015 \\
(2.60) \\
{[1.53]}\end{array}$ & $\begin{array}{c}0.015 \\
(2.86) \\
{[1.81]}\end{array}$ & $\begin{array}{c}0.014 \\
(2.74) \\
{[1.96]}\end{array}$ & $\begin{array}{c}0.010 \\
(2.17) \\
{[1.46]}\end{array}$ & $\begin{array}{c}0.007 \\
(1.43) \\
{[1.15]}\end{array}$ & $\begin{array}{c}0.004 \\
(0.96) \\
{[0.81]}\end{array}$ \\
\hline Works part-time & $\begin{array}{c}0.023 \\
(4.47) \\
{[1.90]}\end{array}$ & $\begin{array}{c}0.023 \\
(5.46) \\
{[2.38]}\end{array}$ & $\begin{array}{l}0.022 \\
(5.04) \\
{[2.79]}\end{array}$ & $\begin{array}{l}0.012 \\
(3.07) \\
{[1.77]}\end{array}$ & $\begin{array}{c}0.007 \\
(1.83) \\
{[1.41]}\end{array}$ & $\begin{array}{c}0.004 \\
(0.96) \\
{[0.77]}\end{array}$ \\
\hline Lives in on-campus housing & $\begin{array}{c}-0.030 \\
(-5.69) \\
{[-2.43]}\end{array}$ & $\begin{array}{l}-0.030 \\
(-6.77) \\
{[-2.80]}\end{array}$ & $\begin{array}{c}-0.033 \\
(-7.78) \\
{[-3.53]}\end{array}$ & $\begin{array}{c}0.005 \\
(1.28) \\
{[0.77]}\end{array}$ & $\begin{array}{c}0.011 \\
(2.98) \\
{[2.05]}\end{array}$ & $\begin{array}{l}0.010 \\
(2.73) \\
{[2.04]}\end{array}$ \\
\hline Lives in a fraternity/sorority & $\begin{array}{c}0.015 \\
(0.66) \\
{[0.27]}\end{array}$ & $\begin{array}{c}0.016 \\
(0.93) \\
{[0.34]}\end{array}$ & $\begin{array}{c}0.019 \\
(1.05) \\
{[0.45]}\end{array}$ & $\begin{array}{c}-0.015 \\
(-0.80) \\
{[-0.45]}\end{array}$ & $\begin{array}{c}0.016 \\
(0.98) \\
{[0.74]}\end{array}$ & $\begin{array}{c}0.028 \\
(1.61) \\
{[1.18]}\end{array}$ \\
\hline Father has alcohol/drug problems & $\begin{array}{c}0.038 \\
(9.30) \\
{[6.33]}\end{array}$ & $\begin{array}{c}0.037 \\
(9.79) \\
{[6.96]}\end{array}$ & $\begin{array}{l}0.038 \\
(9.92) \\
{[7.21]}\end{array}$ & $\begin{array}{c}0.034 \\
(9.81) \\
{[8.14]}\end{array}$ & $\begin{array}{r}0.037 \\
(10.90) \\
{[9.12]}\end{array}$ & $\begin{array}{r}0.038 \\
(11.12) \\
{[9.62]}\end{array}$ \\
\hline 1990 & $\begin{array}{l}-0.015 \\
(-3.61) \\
{[-1.22]}\end{array}$ & $\begin{array}{c}-0.014 \\
(-3.49) \\
{[-1.16]}\end{array}$ & $\begin{array}{l}-0.015 \\
(-3.62) \\
{[-1.42]}\end{array}$ & $\begin{array}{c}0.014 \\
(2.38) \\
{[1.78]}\end{array}$ & $\begin{array}{l}0.013 \\
(2.23) \\
{[1.50]}\end{array}$ & $\begin{array}{c}0.004 \\
(0.67) \\
{[0.40]}\end{array}$ \\
\hline 1991 & $\begin{array}{c}-0.017 \\
(-5.05) \\
{[-1.95]}\end{array}$ & $\begin{array}{c}-0.009 \\
(-2.58) \\
{[-1.00]}\end{array}$ & $\begin{array}{c}-0.013 \\
(-3.55) \\
{[-1.53]}\end{array}$ & $\begin{array}{c}-0.004 \\
(-1.65) \\
{[-1.07]}\end{array}$ & $\begin{array}{c}-0.001 \\
(-0.38) \\
{[-0.25]}\end{array}$ & $\begin{array}{l}-0.001 \\
(-0.43) \\
{[-0.30]}\end{array}$ \\
\hline R-squared & 0.068 & 0.069 & 0.073 & 0.029 & 0.030 & 0.031 \\
\hline F-statistic & 358.383 & 333.723 & 297.701 & 113.045 & 105.672 & 92.117 \\
\hline Wu F-ratio & 5.443 & 11.276 & 9.678 & 1.419 & 0.099 & 0.893 \\
\hline
\end{tabular}

${ }^{a}$ Asymptotic t-statistics in parentheses, Huber t-statistics in brackets, and intercepts not shown. For Wu $\mathrm{F}$ test, critical values of $\mathrm{F}(1, \infty)$ are 3.84 at 5 percent and 6.64 at 1 percent. 
Table 8

Elasticities of Violence With Respect to Number of Drinks

\begin{tabular}{lccc}
\hline & $\begin{array}{c}\text { Beer price and } \\
\text { individual } \\
\text { characteristics }\end{array}$ & $\begin{array}{c}\text { Beer price, marijuana } \\
\text { decriminalization, } \\
\text { income, outlets and } \\
\text { individual } \\
\text { characteristics }\end{array}$ & $\begin{array}{c}\text { Beer price, marijuana } \\
\text { decriminalization, } \\
\text { income, outlets, religion } \\
\text { and individual } \\
\text { characteristics }\end{array}$ \\
\hline TROUBLE & 0.544 & 0.254 & 0.397 \\
Two-stage least squares & 0.477 & 0.477 & 0.476 \\
Ordinary least squares & & & \\
DAMAGE & 0.629 & 0.642 & 0.628 \\
Two-stage least squares & 0.585 & 0.585 & 0.583 \\
Ordinary least squares & & & 0.384 \\
FIGHT & 0.388 & 0.391 & 0.266 \\
Two-stage least squares & 0.269 & 0.269 & \\
Ordinary least squares & & & 0.236 \\
SEXUAL ADVANTAGE & 0.457 & 0.304 & 0.302 \\
Two-stage least squares & 0.304 & 0.304 & \\
Ordinary least squares & & & \\
\hline
\end{tabular}

